\title{
LITIGATING SHUT-IN FOR LACK OF A MARKET: A COMMENT ON SteWART Estate V. TAQA NorTh LTD.
}

\author{
WAYNE RENKE*
}

Typically an Alberta freehold petroleum and natural gas lease continues for a defined period or "primary term”) and so long thereafter as leased substances are produced from the leased lands or the lessee satisfies specified lease conditions. In exchange for the lessee's rights to explore for and produce leased substances, the lessor receives a royalty. This arrangement works satisfactorily, for the most part, when leased substances are produced. Circumstances, though, may disincline the lessee to produce and incline the lessee to shut-in a well, particularly when the well is productive of natural gas. For example (especially if the well is in a new or little-developed location), pipelines may have to be constructed, there may be no nearby pipeline system to connect to, or there may be no readily available processing plants. Purchase contracts must be secured. ${ }^{1}$ Unlike oil, natural gas cannot simply be trucked to another location for disposition. The most convenient means for storing the natural gas pending changed circumstances may be to leave it in the ground. To preserve both a lease and its financial viability, a lessee may seek to rely on lease provisions permitting a well to be shut-in and for the lease to be continued on the payment of shut-in royalties. A lessee would favour an expansive approach to shut-in provisions. In contrast, a lessor would understandably prefer to receive royalties on actual production (which presumably would be greater than shut-in royalties) or to have the lease terminate so that a lessee with a more aggressive or economical approach to production could be found. A lessor would favour a restrictive approach to shut-in provisions.

This conflict between the interests of lessees and lessors relating to contractually justifiable shut-in lies at the heart of Justice Barbara Romaine's decision in Stewart Estate v. TAQA North Ltd. ${ }^{2}$ Many leases entered into in the 1960s and 1970s employ language similar to the leases considered in Stewart, so the case will affect the rights of many lessors and lessees. ${ }^{3}$ Justice Romaine's decision is also valuable as a thorough canvassing of the sequence of issues that must be confronted in shut-in litigation and has the virtue, in my estimation, of landing correctly on the key legal issues (other than a limitations period issue). The decision illuminates the challenges faced by lessees and particularly lessors in shut-in litigation.

* Justice of the Court of Queen's Bench of Alberta. Professor Emeritus and former Vice Dean, Faculty of Law, University of Alberta. This comment was submitted prior to appointment.

Eugene Kuntz, Kuntz, A Treatise on the Law of Oil and Gas (Cincinnati: Anderson Publishing Co, 1990) vol 4 at 3; WL Summers, The Law of Oil and Gas: With Forms, 3rd ed (St Paul, Minn: Thomson/West, 2006) vol 2 at 302; John S Lowe, Oil and Gas Law in a Nutshell, 4th ed (St Paul, West Group, 2003) at 262 .

22013 ABQB 691, 576 AR 57, Romaine J [Stewart]. The appeal of this case was heard in September 2014. The application of the Freehold Petroleum and Natural Gas Owners Association (FOA) for leave to intervene in the appeal was denied (2014 ABCA 222, 577 AR 57, Rowbotham JA [Stewart Intervention Decision]), as was the application for leave to intervene by Wheatland Farming Co Ltd (2014 ABCA 296, [2014] AJ No 980 (QL), Martin JA [Wheatland Intervention Decision]). Wheatland, it appears, has commenced its own action in the Court of Queen's Bench respecting its mines and mineral rights (Wheatland Intervention Decision, ibid at para 7).

3 Stewart Intervention Decision, ibid at para 6 (referring to the affidavit of David Speirs, a director of the FOA). 
After (I) reviewing the basic facts of the case, this comment will consider its main issues: (II) whether a declaration that certain leases had terminated could be granted without purported assignees of the lessor being before the Court; (III) whether any of the plaintiffs' claims were barred by estoppel, acquiescence or laches, or through the operation of the Limitations Act; ${ }^{4}$ (IV) the interpretation of the applicable shut-in clauses and whether, on the evidence, the conditions for shut-in were satisfied; and (V) if the leases terminated the cause or causes of action for which the defendants would be liable and the appropriate measure of damages.

\section{BASIC FACTS}

The action concerned a section of land near Crossfield, Alberta, north of Calgary: section 25 , township 27, range 1 , west of the fifth meridian (the Lands). The relevant surface and mines and minerals rights were held in freehold. ${ }^{5}$ The northwest, southwest, and southeast quarter sections were each the subject of separate oil and gas leases; the northeast quarter section contained two separately leased parcels (cumulatively, the Leases). The Leases were granted in the 1960s and were duly protected by caveats. The plaintiffs were the registered owners of the Lands and parties claiming under Leases, as well as parties interested under a top lease (the Top Lessee Plaintiffs). The defendants were resource company successors to the original lessees (the Defendants). ${ }^{6}$

Each Lease had a 10-year primary term and provided for continuation on production. ${ }^{7}$ The Lands overlay natural gas-bearing formations. In accordance with Lease terms, the Leases were duly pooled by agreement to achieve the requisite drilling spacing unit for natural gas. Upon pooling, production from or shut-in royalties relating to a well on pooled Lands would sustain all the pooled Leases. A well was drilled on legal subdivision 7 in the southeast quarter section of the Lands within the primary term of the Leases (the 7-25 Well). The 7-25 Well encountered two productive formations - the Basal Quartz and the Crossfield. ${ }^{8}$ The Basal Quartz was shallower and sweet; the Crossfield was deeper and very sour. The 7-25 Well was initially completed in the Basal Quartz, from which it produced commencing in March 1971.

The Lands were located in a prolific drilling area. ${ }^{9}$ Because of competitive drainage from the Basal Quartz, it was decided that the 7-25 Well would be recompleted in the Crossfield formation. The 7-25 Well was completed in this formation and produced natural gas from March 1981 until July 1995. For reasons to be elaborated below, the 7-25 Well was shut-in from the end of July 1995 until January 2001. In early 2001, the 7-25 Well was again recompleted in the Basal Quartz and produced from February 2001 to 13 January 2011, when

RSA 2000, c L-12.

Stewart, supra note 2 at paras 5-7.

Justice Romaine summarized the leasehold interests in Appendix A of her decision: ibid, Appendix A (see also paras 22-45).

Ibid at paras 8-21.

See Alberta Energy Regulator, Table of Formations, Alberta (June 2013), online: <www.aer.ca/ documents/catalog/TOF.pdf>.

See Kallisto Energy Corp: Application for a Well Licence — Crossfield East Field (23 July 2013), 2013 ABAER 013, online: Alberta Energy Regulator<www.aer.ca/documents/decisions/2013/2013-ABAER013.pdf $>$ [Kallisto]. 
it was shut-in to comply with an injunction. It appears that the 7-25 Well's reinvigorated production was actually from a neighbouring commercial gas storage unit. ${ }^{10}$

Each of the registered owners of the Lands granted a top lease to Freehold Solutions Inc. (FSI), which in turn created 1088924 Alberta Ltd. (108). FSI assigned its top leases to 108. FSI, 108, and Timothy Bowes, president of FSI and 108, were Plaintiffs. Each top lease was to take effect only on the termination of the existing leases. ${ }^{11}$ As part of the top lease arrangements, FSI agreed to pay legal costs for the litigation. It would split damages with the other Plaintiffs on a fifty-fifty basis. ${ }^{12}$

The action raised no delay rental or "drilling over" issues. ${ }^{13}$ The validity of the Leases was not challenged on the basis of royalty or shut-in royalty calculations, payees, or payment timing. The central issue was whether the Leases had terminated because of the 1995-2001 shut-in. Before addressing this issue, Justice Romaine considered whether, given the parties before the Court, a declaration respecting the termination of certain Leases could be granted, and whether all or any part of the claims were barred through the passage of time, the plaintiffs' conduct, or both.

\section{PARTies Required For a Declaration}

The issue of the proper parties required to support a declaration involves the audi alteram partem ("hear the other side") principle: no one should be condemned unheard. ${ }^{14}$ That principle, one of simple fairness, should apply whenever recourse is had to a state-based procedure that would affect others' rights and interests.

The difficulty faced by certain plaintiffs in Stewart was that, on the evidence, their interests were legally intertwined with other persons' interests, but those other persons were not parties to the litigation. The absence of interested parties is not a common trial problem, since parties issues are typically sorted out before trial or at least before judgment. If at trial a party can point to evidence supporting the conclusion that the proper determination of an opponent's claim for relief requires the participation of another person who is not a party, the

$10 \quad$ Stewart, supra note 2 at para 21; ibid at paras 15, 33.

11 Stewart, ibid at paras 6, 54-74, 99, 102-104.

12 Ibid at para 686. As for the Top Lessee Plaintiffs, very briefly: 108's pleadings claimed damages for trespass, conversion, and unjust enrichment. Justice Romaine accepted that 108 had a sufficient interest to support standing for a declaration of Lease termination. However, since 108 had no possessory interests it lacked status to advance claims for trespass or conversion, and because it held only a contingent interest, it had no claim for unjust enrichment, which was conceded at trial (paras 105, 17682). 108 made an alternative claim based on "loss or delay in being able to take possession of the lands and produce leased substances” (para 179). Because the top leases would not come into effect until the original leases had been terminated and that determination had not been made, 108's rights to proceed with development had not been impaired (paras 179-80). The Defendants counterclaimed against 108 and Bowes for (inter alia) champerty and maintenance (para 681). The success of these claims depended on showing that 108 and Bowes had no legitimate interests in the litigation. Justice Romaine dismissed these claims on the grounds that under the top leases 108 and Bowes had a sufficient "commercial interest,” stating: “Concerns about any impropriety in their role in the litigation can be addressed through the mechanism of costs" (para 690).

13 That is, there were no contentions that the Leases terminated during the primary terms because delay rental was not paid, paid late, paid to incorrect persons, paid in the incorrect amounts, and no contention that the leases terminated because of lack of production before the end of the primary term.

14 See e.g. A (LL) v B (A), [1995] 4 SCR 536 at para 27; Canadian Union of Public Employees, Local 301 v Montreal (City), [1997] 1 SCR 793 at para 73; Winnipeg Child and Family Services v KLW, 2000 SCC 48, [2000] 2 SCR 519 at para 115. 
opponent must discharge the burden of establishing that the appropriate parties are indeed before the court. Otherwise, the court cannot rule on the opponent's claim. ${ }^{15}$ The general rule, according to the Court of Appeal, is that "all parties to a contract must be before the court to enable it to fully adjudicate the issues in question": ${ }^{16}$

\begin{abstract}
The purpose of this rule is to ensure: (i) no injustice is done to any party to an action or other interested persons; (ii) the parties are not prejudiced by not having all proper parties before the court; (iii) all interested parties will be bound by the decision so there is no risk of subsequent proceedings by persons not before the court and thus avoid the need for multiple suits; and, (iv) the court will be able to effectively adjudicate all issues in question.... The court must be "perfectly certain that no injustice is done, either to the parties before it, or to others who are interested in the subject matter". 17
\end{abstract}

In this case, without the participation of the non-parties, the relevant lease termination issues could not be properly adjudicated. Given the multiple interests and skeins of rights and duties swirling around patches of ground from which oil or gas are produced, particularly when lessor and reversionary interests are held separately, this case serves as a good reminder to identify and manage potentially relevant claims before proceeding too far in litigation.

The parties' issue concerned plaintiffs who were successors in interest to Merville Stewart - Jerome Development Limited (JDL) and a group of individual heirs (together, the Jerome Group Plaintiffs). ${ }^{18} \mathrm{Mr}$. Stewart had been the registered owner and original lessor of the south parcel in the northeast quarter section and the southeast quarter section of the Lands (the Stewart Lands). Scurry Rainbow Oil Limited was the named lessee in both leases (the Scurry Leases). In March 1972, Mr. Stewart transferred an undivided 50 percent of his interest in the northeast quarter section to JDL retaining the other 50 percent, which later passed by inheritance to the individual heirs (the Stewart Heirs). In March 1972, Mr. Stewart also transferred all of his interest in the southeast quarter section to JDL. ${ }^{19}$

Had these been the only dispositions of the Stewart Lands, the claims of the Jerome Group Plaintiffs could simply have been considered on the merits. The evidence, however, was that on 1 March 1977, Mr. Stewart assigned his rights as lessor under the Scurry Leases to Snell Farms Ltd. (Snell Farms). ${ }^{20}$ Notice of the assignments was duly provided to the appropriate lessees and assignees, and royalties were paid to Snell Farms. In June 1982, Snell Farms

Stewart, supra note 2 at paras 109, 120, 122; Alberta (Treasury Branches) $v$ Ghermezian, 2000 ABCA 228, 266 AR 170 at para 15 [Alberta (Treasury Branches)]; Looker v Imperial Oil Limited, [1944] OWN 167 at 169 (H Ct J), Conant M [Looker]; see also Coulson v Secure Holdings Ltd (1976), 1 CPC 168 at paras 16-17 (Ont CA) [Coulson].

16 Alberta (Treasury Branches), ibid. This approach is consistent with section 8 of the Judicature Act, RSA 2000, c J-2, s 8:

The Court in the exercise of its jurisdiction in every proceeding pending before it has power to grant and shall grant, either absolutely or on any reasonable terms and conditions that seem just to the Court, all remedies whatsoever to which any of the parties to the proceeding may appear to be entitled in respect of any and every legal or equitable claim properly brought forward by them in the proceeding, so that as far as possible all matters in controversy between the parties can be completely determined and all multiplicity of legal proceedings concerning those matters avoided. For some historical observations concerning the linkage of the Judicature Act and the Alberta Rules of Court, Alta Reg 124/2010, see Carmacks Construction Ltd v Beaumont (Village) and Pentagon Industries Ltd (1981), 30 AR 328 at paras 9-26 (QB).

Alberta (Treasury Branches), supra note 15 at para 15 [citations omitted].

Stewart, supra note 2 at paras 33, 85-87.

Ibid at paras 33-35, 86-88.

Ibid at paras 77, 90-94. 
changed the royalty payee to Wheatland Farming Co. Ltd. (Wheatland), which thereafter received royalty and shut-in royalty payments. ${ }^{21}$ Mr. Stewart died in 1984 . None of the Jerome Group Plaintiffs received royalties from the Scurry Leases, nor did they, for some 35 years, register complaints respecting their lack of receipt of royalties. On this evidence, the Defendants had successfully raised the issue of whether parties other than the Jerome Group Plaintiffs had interests in the Scurry Leases. Critically, neither Snell Farms nor Wheatland were parties to the action.

The non-participation of Snell Farms and Wheatland created this problem: there is a distinction between lessor rights under a lease and reversionary interests in land subject to a lease. ${ }^{22}$ If Snell Farms and Wheatland were lessors by assignment, they (and not the Jerome Group Plaintiffs) would have the right to decide whether or not to claim that the Scurry Leases had terminated. The Jerome Group Plaintiffs would be reversionary interest owners only. They would have interests in the lease validity issue (that is, they would have full rights to the mines and minerals if the Leases terminated), but they would not have the only interests at stake. Further, defences to lease termination could potentially be advanced based on the conduct of Snell Farms and Wheatland as lessors. The evidence then supported live issues respecting whether the validity of the Scurry Leases could be determined without the participation of Snell Farms and Wheatland.

There would have been no procedural impediment to adding Snell Farms and Wheatland as parties prior to the close of pleadings ${ }^{23}$ or after the close of proceedings, on Court order. ${ }^{24}$ Instead, the strategy pursued by the Jerome Group Plaintiffs was to attempt to demonstrate that Snell Farms and Wheatland could not have interests in the Lands, either at all or recognizable in this action, so their absence was of no legal consequence. In aid of this position, the Jerome Group Plaintiffs made a late application to introduce fresh evidence concerning "new developments” involving Snell Farms. This application was subsequently abandoned. ${ }^{25}$ The Jerome Group Plaintiffs further deployed a large array of arguments to remove Snell Farms and Wheatland from legal consideration. The arguments, broadly, were as follows: (1) that Snell Farms and Wheatland could not have received any interests from Mr. Stewart; (2) (if they could) the evidence did not support a finding that Snell Farms and Wheatland were valid assignees of lessor interests; (3) (if they could and did receive interests) any interests that Snell Farms or Wheatland may have had were lost through the operation of the Land Titles Act; ${ }^{26}$ and (4) (if they could and did receive subsisting interests) the Defendants were not entitled to rely on any rights held by Snell Farms or Wheatland. The Jerome Group Plaintiffs lost on all counts, and deservedly so. The fundamental difficulty was that the Jerome Group Plaintiffs could not find a way to immunize themselves from the Snell Farms and Wheatland claims without implicating the rights of Snell Farms and Wheatland. That is, the problem of absent parties recurred in the arguments advanced to show that that there was no problem of absent parties. In yet other words, the Jerome Group Plaintiffs could

Another company, Fairholm Development, also appears to have been a royalty payee, but this matter is not pursued in the reasons (ibid at paras 75,81 ).

Ibid at para 125.

See Alberta Rules of Court, supra note 16, r 3.70(1).

Ibid, r 3.74(2), unless "prejudice would result for a party that could not be remedied by a costs award, an adjournment or the imposition of terms" (ibid, r 3.74(3)).

Stewart, supra note 2 at paras 112-15.

Land Titles Act, RSA 2000, c L-4. 
not succeed without begging the questions respecting the interests of Snell Farms and Wheatland. Justice Romaine properly concluded that she could not be "perfectly certain” that Snell Farms and Wheatland had no relevant rights or interests.

If Mr. Stewart had transferred all of his interests in relation to the Stewart Lands to JDL, no interests would have been left to assign to Snell Farms — nemo dat quod non habet. The difficulty was that the evidence supported the conclusions that Mr. Stewart transferred only his reversionary interests to JDL and assigned his lessor interests to Snell Farms. The issue of what was transferred to JDL and what was left for Snell Farms could not be resolved absent the participation of Snell Farms and Wheatland. ${ }^{27}$ Moreover, the nemo dat argument would not avail respecting the 50 percent undivided interest not transferred by Mr. Stewart to JDL.

On the evidential issues, Justice Romaine held that the burden of proving that Snell Farms and Wheatland held valid assignments did not rest on the Defendants. The Defendants had discharged their burden by showing that Snell Farms and Wheatland were "interested parties”; that is, they had litigable claims respecting their assignments. The Jerome Group Plaintiffs then had the burden of establishing that they, and not Snell Farms or Wheatland, had the only relevant interests in the Stewart Lands. ${ }^{28}$ The Jerome Group Plaintiffs contended that the evidence relating to the assignments was inadmissible. ${ }^{29}$ Justice Romaine found that certain correspondence relevant to the giving of notice of the assignments ("corroborative" or circumstantial evidence) was admissible through exceptions to the hearsay rule. ${ }^{30}$ The claim that the assignments themselves were hearsay was based on a misapprehension. These were not records sought to be admitted as proof of the truth of their contents, as if the documents were asserting factual propositions; rather, the assignments were documents purporting to have legal effects according to their terms (the documents were "verbal" — or better, "legal" - acts, relevant because the words were used, not because the words were conveying facts). ${ }^{31}$ The real issue for this evidence was not its admissibility but its interpretation. But again, absent the participation of Snell Farms and Wheatland, the interpretation issue could not be determined. ${ }^{32}$

The Jerome Group Plaintiffs’ Land Titles argument was intriguing and their strongest weapon. The argument turned on the failure of Snell Farms and Wheatland to caveat their interests. The argument was that the Stewart Heirs and later JDL, which became registered owner of all of the Stewart Lands before trial, took title free from any unregistered interests of Snell Farms and Wheatland. If the register governed, the Jerome Group Plaintiffs were free from the claims of Snell Farms and Wheatland. That is, the Land Titles argument would

Stewart, supra note 2 at paras 124-28.

Ibid at paras 119-23.

Ibid at paras 148-51, 157-63.

Ibid at paras 148-51.

S Casey Hill, David M Tanovich \& Louis P Strezos, McWilliams' Canadian Criminal Evidence, 4th ed (Toronto: Thomson Reuters, 2012) (loose-leaf updated 2012, release 26), ch 7 at 32; Alan W Bryant, Sidney N Lederman \& Michelle K Fuerst, Sopinka, Lederman \& Bryant: The Law of Evidence in Canada, 3rd ed (Markham, Ont: LexisNexis Canada, 2009) at 236: "a distinction must be drawn between statements which evidence a particular conduct or verbal act and are submitted for this purpose, and those statements which are tendered as evidence of the narration. Only the latter are prohibited by the [hearsay] rule." 
make it "perfectly certain" that Snell Farms and Wheatland did not have interests that needed to be taken into account. The main obstacle to Jerome Group Plaintiff success was, once again, the absence of the persons who would be directly affected by the arguments, Snell Farms and Wheatland, coupled with some uncertainty about how the law would apply in the circumstances.

One source of legal uncertainty concerned the scope of protection afforded Snell Farms and Wheatland by the Defendants' caveats. There is some authority that a lessee's caveat provides protection for a lessor's interests; ${ }^{33}$ in turn it may be argued that assignees of a lessor (such as Snell Farms and Wheatland) may also be protected under the lessee's caveat. $^{34}$

A second source of uncertainty concerned the Stewart Heirs, who took by succession and not for value. The traditional claim has been that volunteers cannot rely on registration to defeat unregistered interests. ${ }^{35}$ Justice Slatter has raised significant doubts about the accuracy of this claim. ${ }^{36}$ Turta teaches that a purchaser need not rely on the register to receive indefeasibility protection. ${ }^{37}$ It appears inconsistent, absent contrary statutory warrant, to deny a volunteer indefeasibility protection for failure to "rely on the register." The "volunteer" issue was certainly worthy of consideration and determination on evidence and argument to which all interested parties could contribute.

A third source of uncertainty related to JDL. Justice Romaine suggested that the transfer by the Stewart Heirs to JDL on the eve of trial (which might have cured any weakness in their title as volunteers) could be argued to have been Land Titles fraud. One might observe that the transaction did take advantage of the law, but so do many other forms of unimpeachable conduct (tax planning included). Land Titles fraud includes deceit and dishonesty (which were not in evidence here), but not registration with mere knowledge of a prior unregistered interest. For registration with knowledge of a prior unregistered interest to constitute Land Titles fraud, “something more” is required..$^{38}$ In Darnley, Justice Slatter considered the following factors to be relevant to the issue of whether "something more" was present: the party seeking to rely on indefeasibility was the very party that created the interest at stake, and when the interest at stake was created, that party held a partial interest in the

$33 \quad$ Hughes $v$ Gidosh (1970), [1971] 1 WWR 641 at 652-53 (Alta SC), Greschuk J.

Ibid at 653. However, Gas Exploration Company of Alberta Ltd and Lee v Cugnet, [1954] 12 WWR (NS) 177 (Sask QB), on which Justice Greschuk relied, concerned assignees of the lessee rather than the lessor.

35 Kaup v Imperial Oil Ltd, [1962] SCR 170 at 182-83, Justice Martland stating:

When regard is had to these sections it appears that the conclusiveness referred to in s. 44 is for the benefit of the bona fide purchaser for valuable consideration only ... I do not find anything in the case of CPR and Imperial Oil Ltd v Turta ... which is contrary to this view.... It emphasizes the special position enjoyed, under the Act, by the bona fide purchaser for value. In the present case, admittedly, the appellants are not in that position, it having been conceded that no consideration was given for the transfer which was made by Mrs. Kaup to herself and her husband [citations omitted].

See also Krautt's Estate v Paine (1980), 25 AR 390 at para 8 (CA), Laycroft JA.

Darnley v Tennant, 2006 ABQB 575, 408 AR 261 at paras 20-29, Slatter J [Darnley].

Canadian Pacific Railway Co v Turta, [1954] SCR 427 at 456-57, Rand JA; Turta v CPR, [1953] 4 DLR

87 at 96-102 (Alta SC (AD)), Parlee JA.

Land Titles Act, supra note 26, s 203(3): "The knowledge of the person that any trust or interest that is not registered by instrument or caveat is in existence shall not of itself be imputed as fraud”; Darnley, supra note 36 at para 30. 
lands, so that it merely changed "the quantum or extent of [its] interest." ${ }^{39}$ In this case, Mr. Stewart, not JDL and not the Stewart Heirs (purportedly) assigned his lessor rights. Neither JDL nor the Stewart Heirs had transactions with Snell Farms or Wheatland. To transform the Stewart Heirs and JDL situation into a Darnley situation, a basis would have to be provided for identifying JDL, a separate legal entity, with Mr. Stewart at the time of the assignment. That is, the corporation would have to be identified with the individual's act, not, as is usual in "piercing the veil" cases, identifying the individual with the corporation's act (a sort of "reverse piercing" is at play). Furthermore, there would have to be a basis for concluding that any identification between JDL and Mr. Stewart persisted after his death, so that JDL (as in Darnley) merely changed the quantum or extent of its interest after the Snell Farms interest was created. While the Land Titles fraud argument does not appear strong, once again Snell Farms and Wheatland should have been entitled to add their perspectives.

The late transfer from the Stewart Heirs to JDL troubled Justice Romaine. She also suggested that it might disentitle the Jerome Group Plaintiffs from obtaining a declaration. The decision to grant a declaration is discretionary and "equitable principles, including the conduct of the party seeking the relief" may be taken into account. ${ }^{40}$ The late transfer, made with full knowledge of the Snell Farms and Wheatland claims, and, indeed, made to defeat those claims, may have precluded declaratory relief. The Jerome Group Plaintiffs may have sought equity without clean hands. ${ }^{41}$ It is true that a maxim of Equity is that "he who comes into Equity must come with clean hands." ${ }^{22}$ The maxim, though, does not provide guidance respecting conduct that would be characterized as clean or unclean. ${ }^{43}$ The Stewart Heirs and JDL were doing nothing illegal. They had no direct contact with Snell Farms or Wheatland. It's not clear that their hands were "not clean.” The Stewart Heirs and JDL conduct seems to fall close to this observation by Justice Sopinka in Hongkong Bank: "mere knowledge that one is participating in a transaction which constitutes a breach of a contract to which one is not a party does not seem to me to be sufficient to constitute unclean hands."44 But again, any weakness in this counterattack on the Jerome Group Plaintiffs is not decisive given the other arguments and the absence of Snell Farms and Wheatland from the proceedings.

Even if Snell Farms or Wheatland held interests respecting the Lands, the Jerome Group Plaintiffs contended that the Defendants could not rely on those interests. First, they claimed that the Defendants' reliance on the assignments was not properly pleaded. Justice Romaine found, though, that notice was provided through the litigation process. Regardless, "[t]he possibility of an error in pleading does not address the prejudice to third parties and the possibility of injustice that underpin the general rule requiring all interested parties to be

Stewart, supra note 2 at para 147.

Ibid; Hongkong Bank of Canada v Wheeler Holdings Ltd, [1993] 1 SCR 167 at 189-92, Sopinka JA

[Hongkong Bank] (Justice Sopinka referred to the controversies about whether declarations were or have retained status as an equitable remedy, but concluded, regardless, that "in the exercise of the discretion whether or not to grant a declaration, the court may take into account certain equitable principles such as the conduct of the party seeking the relief" including whether the party seeking the declaration came to Court with “unclean hands" at 192). See also Sattva Capital Corp v Creston Moly Corp, 2014 SCC 53, [2014] 2 SCR 633, Rothstein JA [Sattva] ("misconduct related to the dispute that gave rise to the proceedings may justify the exercise of discretion to refuse the relief sought" at para 98). James Edelman, "The Maxims of Equity" in John McGhee, ed, Snell's Equity, 32nd ed (London: Thomson Reuters, 2010) 105 at 112 [Edelman, "Maxims"].

43 Ibid at 112-14.

$44 \quad$ Hongkong Bank, supra note 41 at 194. 
before the Court." 45 Second, the Jerome Group Plaintiffs urged that the Defendants could not enforce the assignments. Since they were not parties to those arrangements, the Defendants' reliance on the assignments was barred by privity of contract doctrine. Justice Romaine observed that this argument was misplaced. The Defendants were not seeking to enforce the rights of Snell Farms or Wheatland as against the successors to the original assignor. Rather, they had established that, on the evidence, parties in addition to the Jerome Group Plaintiffs had litigable claims relating to the Scurry Leases, and so the validity of those leases could not be determined without those additional parties. ${ }^{46}$

Thus, the interests of Snell Farms and Wheatland could not be ignored. Justice Romaine could not "be 'perfectly certain' that [she would] be able to effectively adjudicate all issues relating to the assignments and the validity of the leases without Snell Farms and Wheatland as parties to the action." 47 The Snell Farms and Wheatland claims must be "disposed of by due process of law." ${ }^{48}$ Moreover, the Defendants should not be exposed to the prospect of, on the one hand, liability to the Jerome Group Plaintiffs on the basis of a terminated Lease and, on the other hand, liability to Snell Farms and Wheatland on the basis of a nonterminated Lease. ${ }^{49}$

Given live issues relating to non-parties and the need for their participation to resolve issues, courts have in some instances imposed a stay pending addition of the missing parties to the litigation. ${ }^{50}$ In this case, the matter had proceeded to trial without Snell Farms and Wheatland, the Jerome Group Plaintiffs had not applied to add parties, and adding them as parties would have worked significant prejudice to the litigation. ${ }^{51}$ It appears that adding them as parties was not feasible. A stay pending their addition, then, would have been inappropriate.

The Jerome Group Plaintiffs had sought a declaration. They failed to demonstrate that all parties necessary to contribute to the resolution of the issues were before the Court. The Jerome Group Plaintiffs’ application for declarations of termination of the Scurry Leases simply failed:

No relief will issue unless all interested parties to the proceedings are represented or have been duly put in default. The applicant has the burden of demonstrating that those parties who have been served with proceedings are not only interested parties, but are the only interested parties to the application.... In default

$45 \quad$ Stewart, supra note 2 at para 156.

Ibid at paras 152-53.

Ibid at para 112 [citations omitted].

Looker, supra note 15 at 169.

England (AG) v Royal Bank of Canada, [1948] OWN 782 at 784, (H Ct J), Conant M [England]. See also Morandan Investments Ltd v Spohn (1987), 58 OR (2d) 621, Borins DCJ ("[t]he absence of Guaranty Trust as a party may work prejudice to both it and the defendants. It may expose the defendants to a multiplicity of suits and to possible injustice, such as double liability, because Guaranty Trust as a non-party is not bound by any judgment obtained in its absence" at 625).

$50 \quad$ See e.g. Alberta (Treasury Branches), supra note 15 at para 19; Looker, supra note 15 at 169, 171-72; England, ibid at 785.

51 See Alberta Rules of Court, supra note 16, r 3.74(3). See also Stewart, supra note 2 at para 114 (the Defendant's concerns respecting the "fresh evidence" application). 
of service to all those who have or may have an interest, the court would in effect be granting a decree in the air. $^{52}$

Justice Romaine's conclusions were limited to the Jerome Group Plaintiffs. The other plaintiffs (the Plaintiffs) were entitled to proceed with claims for declarations of invalidity of the leases in which they were interested. ${ }^{53}$

\section{BARRED CLAIMS}

Defences turning on delay and lessor conduct during periods of delay are important for freehold lessors, especially when lessees have relied on shut-in provisions to continue leases. Years may pass after ostensible reliance on shut-in provisions (possibly followed by a substantial productive period after a recompletion) before a lessor realizes that the lease may have terminated at or about the time of shut-in. Lessors often would not have had contemporaneous or direct access to information suggesting that a lessee was not entitled to rely on shut-in provisions. Before the realization of the possibility of lease invalidity, lessors may have received shut-in royalties or (later) production royalties, and may have communicated with lessees about other matters.

In this case, the shut-in occurred in 1995 and production resumed following recompletion in 2001, but the action was not commenced until 9 August 2005. The Defendants contended that all or some of the Plaintiffs' claims were barred by the application of either (1) the doctrines of estoppel, laches, and acquiescence or (2) the Limitations Act. ${ }^{54}$

\section{A. ESTOPPEL, LACHES, AND ACQUIESCENCE}

It is customary for challenged lessees to retort that lessors' claims are barred by estoppel, or acquiescence, or laches. ${ }^{55}$ It is customary for these defences to be rejected, ${ }^{56}$ save in quite exceptional cases. ${ }^{57}$ This action followed the customary model — the doctrines barring the Plaintiffs' claims were asserted and swiftly denied.

The Plaintiffs' conduct was typical of lessors in lease termination cases. Prior to their contact with FSI (the top lessee) they had not adverted to the possibility (legal or factual) that

52 Lazar Sarna, The Law of Declaratory Judgments, 3rd ed (Toronto: Thomson Carswell, 2007) at 98; Stewart, ibid at para 109; Local 1571 ILA v International Longshoremen's Association, [1951] 3 DLR 50 at 53 (NBSC (Ch Div)), Justice Harrison stating:

Article 8, s. 1 of the Constitution provides that the officers of the I.L.A. shall be a president, nineteen vice-presidents, and a secretary treasurer. None of these International officers are before this Court and, as stated, there is no evidence that the defendant Galbraith has authority to represent the International officers in this action. There is therefore no jurisdiction in this Court to make the declarations asked for.

Alberta Rules of Court, supra note 23, r 3.73(1).

Stewart, supra note 2 at paras 1-2.

Limitations Act, supra note 4, s 10: "Nothing in this Act precludes a court from granting a defendant immunity from liability under the equitable doctrines of acquiescence or laches, notwithstanding that the defendant would not be entitled to immunity pursuant to this Act."

$56 \quad$ See e.g. Canadian Superior Oil Ltd v Paddon-Hughes Development Co Ltd, [1970] SCR 932 [Canadian Superior]; Sohio Petroleum Co v Weyburn Security Co, [1971] SCR 81 [Sohio]; Republic Resources Ltd and Joffre Oils Ltd v Ballem (1981), 33 AR 385 (QB); Freyberg v Fletcher Challenge Oil and Gas Inc, 2005 ABCA 46, 363 AR 35 [Freyberg CA].

$57 \quad$ Voyager Petroleums Ltd $v$ Vanguard Petroleums Ltd (1982), 47 AR 14 (QB), Stratton J, aff'd (1983), 47 AR 1 (CA), leave to appeal to SCC refused, 18007 (21 November 1983). 
the leases had terminated. After contact with FSI, even though some Plaintiffs continued to receive royalty payments, there was no evidence that any Plaintiff waived its rights, or (importantly) that any Defendant relied on any Plaintiff's conduct to its detriment. After contact with FSI, the Plaintiffs brought their litigation within a reasonable time. ${ }^{58}$

\title{
1. ESTOPPEL AND ACQUIESCENCE
}

An immediate response to the Defendants' pleading of estoppel was that "the Supreme Court has expressed doubt as to whether estoppel could ever operate to revive a terminated lease.”59 The conduct of the Plaintiffs relied on by the Defendants took place after the Leases would have terminated. Even if estoppel were made out, it may have occurred too late to benefit the Defendants. In any event, none of the several forms of estoppel — "proprietary," by convention, or by waiver or election — were established.

Historically, estoppel (in the form of proprietary estoppel or estoppel by acquiescence) has been argued in Alberta oil and gas cases through the medium of Willmott v. Barber and its five "probanda:"

\begin{abstract}
It has been said that the acquiescence which will deprive a man of his legal rights must amount to fraud, and in my view that is an abbreviated statement of a very true proposition. A man is not to be deprived of his legal rights unless he has acted in such a way as would make it fraudulent for him to set up those rights. What, then, are the elements or requisites necessary to constitute fraud of that description? In the first place the plaintiff must have made a mistake as to his legal rights. Secondly, the plaintiff must have expended some money or must have done some act (not necessarily upon the defendant's land) on the faith of his mistaken belief. Thirdly, the defendant, the possessor of the legal right, must know of the existence of his own right which is inconsistent with the right claimed by the plaintiff. If he does not know of it he is in the same position as the plaintiff, and the doctrine of acquiescence is founded upon conduct with a knowledge of your legal rights. Fourthly, the defendant, the possessor of the legal right, must know of the plaintiff's mistaken belief of his rights. If he does not, there is nothing which calls upon him to assert his own rights. Lastly, the defendant, the possessor of the legal right, must have encouraged the plaintiff in his expenditure of money or in the other acts which he has done, either directly or by abstaining from asserting his legal right. Where all these elements exist, there is fraud of such a nature as will entitle the Court to restrain the possessor of the legal right from exercising it, but, in my judgment, nothing short of this will do. ${ }^{60}$
\end{abstract}

The jurisprudence has evolved past Willmott v. Barber (although the probanda continue to exercise influence in Alberta). ${ }^{61}$ Estoppel has three main elements: "a representation or assurance made to the claimant; reliance on it by the claimant; and detriment to the claimant in consequence of his (reasonable) reliance." 62 The knowledge or lack of knowledge (or negligent lack of knowledge) of the person against whom estoppel is urged, however,

Stewart, supra note 2 at paras 222-24.

Freyberg CA, supra note 56 at para 133; Canadian Superior, supra note 56 at 937.

Willmott $v$ Barber (1880), 15 Ch D 96 at 105-106, Fryy J.

Desoto Resources Ltd v Encana Corp, 2010 ABQB 448, 491 AR 97 at paras 49-63, Tilleman J.

Thorner v Major, [2009] UKHL 18, [2009] 3 All ER 945 at para 29, Lord Walker. See also James

Edelman, "Estoppel” in McGhee, supra note 42, 361 at 387; Tretheway-Edge Dyking District v Coniagas Ranches Ltd, 2003 BCCA 197, 224 DLR (4th) 611 at para 64, Newbury JA. 
remains one relevant factor ${ }^{63}$ — for good reason, since the mens rea goes directly to whether or not barring the person's claims would be just. In this case, there was no evidence of detrimental reliance by the Defendants. Neither was there evidence that the Plaintiffs in fact knew of their rights in the mid-1990s or at the time of re-completion of the 7-25 Well. Justice Romaine relied on this finding to reject the application of estoppel. ${ }^{64}$ This was a satisfactory result respecting proprietary estoppel.

Nonetheless, two difficulties with Justice Romaine's brief reasons should be noted. First, Justice Romaine distinguished her estoppel finding from her finding (to be discussed below) respecting the Plaintiffs' constructive knowledge for limitations purposes. Knowledge for estoppel purposes "is a different question from whether they knew or ought to have known the 'injury' for which they were seeking a remedial order had occurred." ${ }^{65}$ That different questions are raised must, of course, be conceded. The same evidence, however, may be relevant to two different facts-in-issue. If the Plaintiffs should have known that they were "injured," would the equities respecting estoppel be affected? Justice Romaine does not pursue this issue, because of the second difficulty. She did not consider whether estoppel might be available, despite the Plaintiffs' lack of knowledge. The modern approach to estoppel contemplates that estoppel may be available, even if the person to be estopped did not subjectively know his, her, or its rights:

In the Taylor Fashions Oliver $\mathrm{J}$ analysed the authorities in a masterly way (with the assistance of two Chancery silks who were later to become law lords) and put this part of the law back on the right track. He pointed out that the five probanda (including the defendant's knowledge of his own title, and of the claimant's mistake as to title) are relevant only to cases of unilateral mistake, where the defendant's only encouragement to the claimant has been passive non-intervention.

Towards the end of his judgment Oliver J made some important general observations:

'Furthermore, the more recent cases indicate, in my judgment, that the application of the Ramsden $v$ Dyson principle (whether you call it proprietary estoppel, estoppel by acquiescence or estoppel by encouragement is really immaterial) requires a very much broader approach which is directed rather at ascertaining whether, in particular individual circumstances, it would be unconscionable for a party to be permitted to deny that which, knowingly or unknowingly, he has allowed or encouraged another to assume to his detriment rather than to inquiring whether the circumstances can be fitted within the confines of some preconceived formula serving as a universal yardstick for every form of unconscionable behaviour. $^{, 66}$

Yeoman's Row Management Ltd v Cobbe, [2008] UKHL 55, [2008] 4 All ER 713 at para 59, Lord Walker [Cobbe]; Lloyds Bank PLC v Carrick, [1996] 4 All ER 630 at 641 (CA); Edelman, "Estoppel," ibid at 388.

$64 \quad$ Stewart, supra note 2 at para 222.

65 Ibid.

66 Cobbe, supra note 63 at paras 58-59 [citations omitted]. 
The following comment by Justice La Forest suggests that inquiries into knowledge for limitations purposes and for estoppel may be closer than Justice Romaine has intimated (although this passage speaks to acquiescence, considered next, rather than estoppel):

It is interesting to observe that in practical terms the inquiry under the heading of acquiescence comes very close to the approach one takes to the reasonable discoverability rule in tort. As we have seen, the latter focuses on more than mere knowledge of the tortious acts - the plaintiff must also know of the wrongfulness of those acts. This is essentially the same as knowing that a legal claim is possible. That the considerations under law and equity are similar is hardly surprising, and is a laudable development given the similar policy imperatives that drive both inquiries. ${ }^{67}$

Estoppel by convention was not established in the circumstances. The "convention" would have been the belief by the Plaintiffs and Defendants that the Leases remained valid. According to Justice Bastarache in Ryan v. Moore, estoppel by convention requires the satisfaction of the following criteria:

The parties' dealings must have been based on a shared assumption of fact or law: estoppel requires manifest representation by statement or conduct creating a mutual assumption. ${ }^{68}$ Nevertheless, estoppel can arise out of silence (impliedly). ${ }^{69}$

(2) A party must have conducted itself, i.e. acted, in reliance on such shared assumption, its actions resulting in a change of its legal position. ${ }^{70}$

(3) It must also be unjust or unfair to allow one of the parties to resile or depart from the common assumption. The party seeking to establish estoppel therefore has to prove that detriment will be suffered if the other party is allowed to resile from the assumption since there has been a change from the presumed position. ${ }^{71}$

Even if a convention could be established, such that the Plaintiffs had communicated their belief that the Leases remained alive to the Defendants (in other words, the Plaintiffs engaged in conduct that crossed the line between lessor and lessee) ${ }^{72}$ the evidence did not

$67 \quad M(K) \vee M(H),[1992] 3$ SCR 6 at 79, La Forest JA [M (K)].

68 See also Ryan v Moore, 2005 SCC 38, [2005] 2 SCR 53, Bastarache JA ("[t]he crucial requirement for estoppel by convention, which distinguishes it from other types of estoppel, is that at the material time both parties must be of 'a like mind"” at para 61 [citations omitted]).

$69 \quad$ See also ibid (" $[\mathrm{w}]$ hile it may not be necessary that the assumption by the party raising estoppel be created or encouraged by the estopped party, it must be shared in the sense that each is aware of the assumption of the other" at para 62 [citations omitted]).

$70 \quad$ See also ibid ("[This] requires a finding that the party seeking to establish the estoppel changed his or her course of conduct by acting or abstaining from acting in reliance upon the assumption, thereby altering his or her legal position” at para 69 [citations omitted]).

$71 \quad$ Ibid at para 59 [citations omitted, emphasis in original].

72 K Lokumal \& Sons (London) Ltd v Lotte Shipping Co Pte Ltd, [1985] 2 Lloyd's Rep 28 (CA), Lord Justice Kerr held at 34-35:

All estoppels must involve some statement or conduct by the party alleged to be estopped on which the alleged representee was entitled to rely and did rely. In this sense all estoppels may be regarded as requiring some manifest representation which crosses the line between representor and representee, either by statement or conduct. It may be an express statement or it may be implied from conduct, e.g. a failure by the alleged representor to react to something said or done by the alleged representee so as to imply a manifestation of assent which leads to an estoppel by silence or acquiescence. Similarly, in cases of so-called estoppels by convention, there must be some mutually manifest conduct by the parties which is based on a common but mistaken assumption. See also Edelman, "Estoppel,” supra note 42 at 368. 
support the conclusion that the Defendants changed their legal position in reliance on the Plaintiffs' communication of their assumption. The Defendants acted for their own reasons, not for reasons supplied by the lessors. Allowing the Plaintiffs to assert the Lease termination against the Defendants, allowing the Plaintiffs to resile from their view that the Leases had been valid, would not be unfair or unjust to the Defendants because of the Plaintiffs' conduct.

Estoppel by waiver or election was not made out, because there was no evidence that the Plaintiffs knew their legal rights and the facts supporting their rights when they received royalties. They could not have made an "informed and unequivocal choice."73

\section{LACHES AND ACQUIESCENCE}

Laches and acquiescence are defences to equitable claims. ${ }^{74}$ The Plaintiffs, then, might have resisted their application to their common law torts claims. However, the Plaintiffs' claims also sounded in unjust enrichment, which at least has roots in equity. ${ }^{75}$ Further, the declaratory remedy sought by the Plaintiffs draws on jurisdictional threads reaching back into the Courts of Chancery. ${ }^{76}$ In any event, a declaration is a discretionary remedy, so if the Plaintiffs had engaged in conduct amounting to acquiescence or laches, that could provide grounds for not granting the declaration. ${ }^{77}$

Laches requires "more than mere delay. The plaintiff must show either acquiescence to the point of waiver, or prejudice or other potential injustice caused by the delay in prosecuting the lawsuit.,"78

Thus, the Supreme Court has made it clear that the defence of laches entails the notion of delay combined with either (a) evidence of conduct revealing that the plaintiff acquiesced in the alleged wrongful act in a way that leads reasonably to the inference that the plaintiff waived its right to a remedy, or (b) evidence that, in reliance on the status quo, the defendant altered its position in a way that constitutes prejudice, or evidence that through its delay, the plaintiff permitted circumstances to arise that it would be unjust to disturb. Therefore, delay will not afford an effective defence until the defendant is able to establish prejudice or other evidence of potential injustice. ${ }^{79}$

Consistently with the doctrine of estoppel, the acquiescence branch of laches requires proof that the delaying party not only knew the relevant facts but knew or should have known that a legal claim (possibly) arose on those facts:

\footnotetext{
Freyberg CA, supra note 56 at paras 125-32.

$M(K)$, supra note 67 at 76.

Peel (Regional Municipality) v Canada, [1992] 3 SCR 762 at 787, McLachlin JA; Pettkus v Becker, [1980] 2 SCR 834 at 847-48; Peter v Beblow, [1993] 1 SCR 980 at 987, McLachlin JA.

76 Sarna, supra note 52 at 4-5, 17; EM Heenan, "History of Declaratory Relief - A Distinct Remedy Beyond Equitable Affiliations” in Kanaga Dharmananda \& Anthony Papamatheos, eds, Perspectives on Declaratory Relief(Sydney, NSW: Federation Press, 2009) 51 at 56-58; Hongkong Bank, supra note 41 at $189-92$.

$77 \quad$ Sarna, ibid at 18; HongKong Bank, ibid at 192.

78 681210 Alberta Ltd v Hunter, 2012 ABCA 83, [2012] 7 WWR 698 at para 33 [681210]; Edelman, "Maxims," supra note 42 at 115.

79 Rivergate Properties Inc v West St Paul (Rural Municipality), 2006 MBCA 76, 271 DLR (4th) 281 at
} para 53, Hamilton JA. See also 681210, ibid at para 32; Eldeman, “Maxims,” ibid at 117-18. 
It is not enough that the plaintiff knows of the facts that support a claim in equity; she must also know that the facts give rise to that claim. However, this Court has held that knowledge of one's claim is to be measured by an objective standard. In other words, the question is whether it is reasonable for a plaintiff to be ignorant of her legal rights given her knowledge of the underlying facts relevant to a possible legal claim. ${ }^{80}$

Justice Romaine held that the Plaintiffs' lack of knowledge, which forestalled the application of estoppel, similarly forestalled the application of the first branch of laches. ${ }^{81}$ Again, Justice Romaine did not explore the operation of constructive knowledge (if any) in the circumstances. But yet again, the Plaintiffs did not cause the Defendants to change their position in reliance on the status quo. As in the case of $M$.(K.) v. M. (H.), we may say "[f]urther, there is nothing about the delay's here rendering further prosecution of the case unreasonable." 82 The Defendants' attempts to bar the Plaintiffs' action through judge-made law grounds failed. These doctrines are more forgiving to lessors than Alberta's Limitations Act.

\section{B. Limitations ACT}

\section{DECLARATIONS}

Fortunately for lessors, the Limitations Act does not constrain applications for declarations alone. The two- and ten-year limitation periods established in section 3 of the Limitations Act concern actions for "remedial orders." Declarations are expressly excluded from the definition of "remedial orders." 83 The Plaintiffs, then, except for the Jerome Group Plaintiffs, were entitled to pursue their applications for declarations that the Leases had terminated. ${ }^{84}$

\section{REMEDIAL ORDERS}

Unfortunately for lessors, the Limitations Act does constrain actions for compensation for periods of alleged wrongdoing by lessees. Section 3(1) of the Limitations Act provides as follows:

if a claimant does not seek a remedial order within

(a) 2 years after the date on which the claimant first knew, or in the circumstances ought to have known,

$M(K)$, supra note 67 at 78-79 [citations omitted]. See also Manitoba Metis Federation Inc $v$ Canada (AG), 2013 SCC 14, [2013] 1 SCR 623, McLachlin CJC and Karakatsanis JA ("acquiescence depends on knowledge, capacity and freedom” at para 147).

$81 \quad$ Stewart, supra note 2 at para 222.

$82 \quad M(K)$, supra note 67 at 78.

83 Limitations Act, supra note 4, s 1(i)(i); Stewart Estate, supra note 2 at para 186; Institute of Law Research and Reform, Limitations: Report for Discussion No 4 (Edmonton: Institute of Law Research and Reform, 1986) [Report No 4], online: <www.alri.ualberta.ca/docs/rfd004.pdf>; Alberta Law Reform Institute, Limitations: Report No 55 (Edmonton: Alberta Law Reform Institute, 1989) at 38 [Report No 55], online: <www.alri.ualberta.ca/docs/fr055/pdf>.

84 Damages claims, however, cannot avoid limitations rules through linkage with applications for declarations: Yellowbird v Samson Cree Nation No 444, 2008 ABCA 270, 433 AR 350 at paras 47-49; Joarcam, LLC v Plains Midstream Canada ULC, 2013 ABCA 118, 90 Alta LR (5th) 208 at para 5; Canadian Natural Resources Ltd v Jensen Resources Ltd, 2013 ABCA 399, 566 AR 76 at para 40 [CNRL]; Sarna, supra note 52 ("[i]f a declaration is merely ancillary to consequential relief which is statute- barred, the entire recourse is considered as consequential relief and will fall” at 4). 
(i) that the injury for which the claimant seeks a remedial order had occurred,

(ii) that the injury was attributable to conduct of the defendant, and

(iii) that the injury, assuming liability on the part of the defendant, warrants bringing a proceeding,

or

(b) 10 years after the claim arose,

whichever period expires first, the defendant, on pleading this Act as a defence, is entitled to immunity from liability in respect of the claim. ${ }^{85}$

The Plaintiffs claimed remedial orders, seeking damages for trespass, conversion, and unjust enrichment.

\section{a. $\quad$ Ten-Year Limitation Period - Section 3(1)(b)}

The ten-year limitation period did not assist the Plaintiffs. It barred certain claims arising “from the Plaintiffs' allegations of historical discriminatory production practices and failure to drill in the Elkton zone." ${ }^{\text {" }} 6$ The calculation of the ten-year limitation period did favour the claims actively pursued by the Plaintiffs. While time begins to run "when the conduct, act, or omission occurred," 87 the actions of the Defendants arguably constituted a continuing course of conduct; the wrongdoing was rolling or continuous. ${ }^{88}$ The Limitations Act provides that

3(3) For the purposes of subsection (1)(b) and (1.1)(b),

(a) a claim or any number of claims based on any number of breaches of duty, resulting from a continuing course of conduct or a series of related acts or omissions, arises when the conduct terminates or the last act or omission occurs. ${ }^{89}$

Since the Defendants remained on the Lands, the limitation period would not have begun to run (let alone expired) by the time of trial. However, a claimant is caught and a defendant is protected by the limitation period that expires first. Justice Romaine found that the limitation period under section 3(1)(a) expired first, long before trial, barring at least a substantial portion of the Plaintiffs' claims.

Limitations Act, supra note 4, s 3(1).

Stewart, supra note 2 at para 183.

WP v Alberta, 2013 ABQB 295, 536 AR 32 at para 17, Rooke J.

Krook v Cold Lake (City), 2010 ABCA 324, 490 AR 237 ("plain reading of this provision requires that the conduct complained about in the statement of claim is caught so long as part of it occurred less than 10 years before the filing of the claim, provided the conduct is a continuous course or consists of a series of related acts” at para 19). See also Bowes v Edmonton (City), 2007 ABCA 347, 425 AR 123, Côté JA; Lewis N Klar, Tort Law, 5th ed (Toronto: Carswell, 2012) at 116.

$89 \quad$ Limitations Act, supra note 4, s 3(3)(a). Note that section 3(3)(a) applies to the section 3(1)(b) limitation period, not the section 3(1)(a) limitation period. 


\section{b. Two-Year Limitation Period - Section 3(1)(a)}

Some aspects of the section 3(1)(a) analysis are clear. The Plaintiffs had the burden of proving that their remedial orders were sought within the section $3(1)$ (a) limitation period. ${ }^{90}$ Time started to run on the date on which the Plaintiffs first knew, or in the circumstances ought to have known, that the injury for which they sought damages

(1) had occurred,

(2) was attributable to conduct of the Defendants, and,

(3) assuming liability on the part of the Defendants, warranted bringing a proceeding.

For Limitations Act purposes, "knowledge" refers to knowledge of the facts supporting a claim, not knowledge that, in law, the facts support a claim. ${ }^{91}$ To know that an injury has occurred, a plaintiff is not required to know that the elements of a cause of action have occurred. $^{92}$

The Plaintiffs knew that the 7-25 Well was shut-in from 1995 to 2001. In 1995 they had ceased to receive royalties and had begun to receive shut-in royalty payments. ${ }^{93}$ Long before commencing their action, they knew that they were lessors, the primary terms of the Leases had expired, and that the Defendants were not producing natural gas. Was that knowledge sufficient to start the limitation period running? Did the Plaintiffs know that an injury had occurred?

In support of the view that the Plaintiffs knew or should have known in the mid-1990s that an injury had occurred, it can be pointed out that the Plaintiffs knew all that a lessor plaintiff needed in order to put a lessee defendant to its defence. ${ }^{94}$ The Plaintiffs did not need to know that a cause of action was made out, but regardless, the shut-in provisions relied on by the Defendants were a defence and not part of the Plaintiffs' cause of action..$^{95}$ The injury that should have been discerned by the Plaintiffs did not include knowledge of facts relating to the Defendants' justification for shutting-in.

$91 \quad$ Stewart, supra note 2 at paras 198, 201, 206; Laasch v Turenne, 2012 ABCA 32 , 347 DLR (4th) 514 at para 24 [Laasch]; CNRL, supra note 84 at para 43; Stobbe v Paramount Investments Inc, 2013 ABCA 384, 566 AR 155 at para 15; Luscar Ltd v Pembina Resources Ltd, 1994 ABCA 356, [1995] 2 WWR 153 at para 129; Report No 4, supra note 83 at 119:

We take particular objection to deferring the commencement of the discovery period until the claimant acquires sufficient legal knowledge to know that a claim would have a reasonable prospect of success. Frequently this will be a very difficult and subjective issue for even the lawyers and judges involved in a case, and requiring a court to determine when a claimant, usually a nonlawyer, had sufficient knowledge of the legal consequences of factual events will further confound the matter. para 11, Berger JA.

$93 \quad$ Stewart, supra note 2 at paras 193, 197.

$94 \quad$ Freyberg CA, supra note 56 at para 76:

The Lease in question has a primary term of five years. It terminates at the end of that time, or on a subsequent anniversary date if the Lease has been extended, if there is no production. Lady Freyberg relies on these provisions to assert that the Lease has terminated. To satisfy her onus she must show that the Lease is valid and that there has been no production. 
The following reflections, however, support the position that the Plaintiffs neither knew or ought to have known of their injury prior to 2003: if "injury” and "cause of action" are not equivalents, knowledge of an injury need not embrace all the elements of a cause of action. But equally, then, knowledge of an injury may embrace elements that fall outside a cause of action. Since injury is not coextensive with cause of action, knowledge of an injury need not be confined to knowledge of what constitutes a cause of action or to the facts that spare a plaintiff from a non-suit application. ${ }^{96}$ The difficulty is that a lessor would not know that it is suffering property damage or economic loss unless it also had some basis for concluding that the lease had terminated. Shut-in by itself, even for a lengthy period, would not necessarily support actual or constructive knowledge of lease termination. Shut-in clauses are elements of leases. Shut-ins may be entirely legitimate. Physically, a legitimate shut-in and an unauthorized shut-in look the same. Shut-in royalties would be in the same amount, whether authorized or unauthorized. For a lessor to have actual or constructive knowledge of injury caused by unauthorized shut-in, the lessor would, or should, be aware of circumstances that support the conclusion (at least the possibility) that the shut-in is unauthorized. Some circumstances beyond shut-in itself and mere delay in production must be accessible to the lessor.

The "something more" needed to support lessors' actual or constructive knowledge may or may not come quickly or easily. The "something more" will be specific to particular lessors and the peculiarities of their environments. A few starting points for the assessment of what lessors knew or should have known are apparent (perhaps falling within the scope of judicial notice). Freehold lessors are typically at a severe informational disadvantage compared to oil and gas companies. Freehold lessors are not usually oil and gas industry professionals. They would not ordinarily have knowledge of the geological or engineering challenges of wells or the economics of production from wells. They would not have information respecting wells in the vicinity of their properties that would inform assessments of their own leases. Lessors must, in practice, rely heavily on lessees to conduct drilling and production operations properly, to account for royalties properly, and, as will be seen, to assess the market properly when considering whether or not to shut-in a well. We would not expect lessors to view all acts of lessees with suspicion and to make constant information requests. In the Meek decision, the Court of Appeal indicated that "[a] royalty interest holder is entitled to expect the royalty payor to honour its obligations."97 Similarly, a lessor should be entitled to expect that a lessee will abide by the terms of a lease. To start the limitations clock running, the trial judge should look for some circumstances raised or should have raised the possibility that the lessee was not following lease terms. Were matters otherwise, lessors would be obliged to commence litigation against lessees at every shut-in, just in case the shut-in was not justified under the lease.

Even if some force were accorded to these reflections, the Court of Appeal has warned against adding language to the Limitations Act. In particular, there is no statutory requirement that a claimant have "clear information" respecting an injury. ${ }^{98}$ The test, as set by the claims, including property damage and economic loss, not to criteria for identifying injury: Limitations Act, supra note 4, s 1(e). 
Limitations Act, is whether the claimant "in the circumstances ought to have known"99 of the claim - that is, whether the claimant was reasonably diligent in determining whether it had a claim, in the claimant's circumstances.

When, then, should the Plaintiffs have known of their injury? The Plaintiffs argued that they did not realize that there were issues relating to the validity of the Leases until December 2003, when they met with counsel. ${ }^{100}$ Once the Plaintiffs had contacted counsel, investigations disclosed sufficient information to permit the Statement of Claim to be filed within a year. Justice Romaine was of the view that the Plaintiffs should have concluded that the shut-in was improper much earlier, within a year of having first begun to receive shut-in royalties: "Even if some knowledge of the reason for the cessation for production was necessary for the Plaintiffs to bring their claims, such knowledge could reasonably have been obtained within a year." ${ }^{\text {"101 }}$ If sufficient information to discern an injury could be gathered in a year after meeting with counsel, sufficient information to discern an injury could have been gathered within a year of receiving shut-in royalties. That would put the Plaintiffs' knowledge of their injuries in the mid-1990s. The section 3(1)(a) limitation period would have long expired before 2005.

One might concede that due diligence steps could have been taken within a year, as Justice Romaine indicated. The difficulty, though, is identifying the trigger event; one year from when? Bearing in mind that the clear information need not have been before the Plaintiffs prior to their meeting with counsel, was there evidence on which a reasonable person would have concluded that it was possible that the shut-in was not authorized under the Leases? Justice Romaine did not refer to any circumstances that would have put a reasonable person on notice that the shut-in was improper. It is true that at least some Plaintiffs knew that they were receiving shut-in royalty payments that were different than production royalty payments. ${ }^{102}$ As indicated above, however, the mere receipt of shut-in payments, even for an extensive period, is not, by itself, evidence of injury. Justice Romaine did not point to evidence of the "something more" that should have alerted the Plaintiffs to the potential impropriety of the shut-in. If "something more" than mere receipt of shut-in royalty payments was needed to support knowledge of impropriety of the shut-in, and if the "something more" did not occur until 2003, the Plaintiffs brought their claims within the limitation period and none of their claims were statute-barred. Of course, the failure of a limitations defence does not guarantee recovery, it only means that the Plaintiffs are entitled to claim what may turn out to be no sustainable cause of action at all.

The Plaintiffs also turned to section 3(1)(a)(iii) of the Limitations Act. ${ }^{103}$ Even if they knew or should have known of their injury earlier, the Plaintiffs claimed that they brought their action within two years of determining that their injuries, "assuming liability on the part of the [Defendants]," warranted bringing a proceeding. The test for whether injuries warrant bringing a proceeding is whether

Limitations Act, supra note 4, s 3(1)(a) [emphasis added].

Stewart, supra note 2 at para 188.

Ibid at para 200.

Ibid at para 193.

Supra note 4. 
a reasonable person would consider that someone in the plaintiff's position, acting reasonably in light of his or her own circumstances and interests, could — not necessarily should — bring an action. This approach is neither purely subjective nor purely objective. The question becomes: "in light of his or her own circumstances and interests, at what point could the plaintiff reasonably have brought an action?” The reasonable person would only consider that the plaintiff could not have brought an action at the time the right to do so first arose if the plaintiff's own interests and circumstances were serious, significant, and compelling. Purely tactical considerations have no place in this analysis. ${ }^{104}$

Since section 3(1)(a)(iii) "[assumes] liability on the part of the defendants," 105 this provision does not relate to whether claimants knew or should have known of an injury. "Injury" should be encompassed in the "liability" that is assumed. The section 3(1)(a)(iii) issue is whether, given an injury, proceeding was warranted. Factors relevant to section 3(1)(a)(iii), then, would not concern whether the claimant knew or should have known about the injury, but whether there were circumstances that did not warrant (or urged or militated against) bringing an action: ${ }^{106}$

As to the third requirement, the discovery period will not begin until the claimant first knew that his injury was sufficiently serious to have warranted bringing a proceeding, that is, there must be relatively serious harm. This criterion will protect litigants from incurring unnecessary legal expenses, and bringing unnecessary legal action. The discovery rule will, in effect, invite the judge to put himself in the claimant's shoes, to consider what knowledge he had at the relevant time, and to make the cost-benefit analysis which would be reasonable for the actual claimant. ${ }^{107}$

\section{As Justice Clackson has observed,}

It is not every nick, bump, bruise, failing or deficiency that warrants action. Thankfully, we Canadians are still reasonably tolerant and non litigious. The question of whether an injury warrants proceedings is not strictly an issue of fault, nor even potential economic gain. What warrants proceedings embraces a consideration of the extent of the injury in comparison to the economics of prospective action. This assessment involves a blended objective [and] subjective analysis. ${ }^{108}$

In this case, the Plaintiffs provided no evidence of the requisite "serious, significant, and compelling” circumstances that would show that bringing an action earlier was not warranted. ${ }^{109}$ Subparagraph 3(1)(a)(iii) did not assist the Plaintiffs.

If my contentions concerning actual or constructive knowledge of injury are correct, the section 3(1)(a) limitation period did not commence until 2004 (one year after contact with

Novak v Bond, [1999] 1 SCR 808 at para 81, McLachlin JA [Novak] [emphasis omitted]. See also $N(J)$ $v$ Kozens, 2004 ABCA 394, 248 DLR (4th) 245 at para 14; Laasch, supra note 91 at para 19; Stewart, supra note 2 at paras 209-10.

Limitations Act, supra note 4, s 3(1)(a)(iii).

Stewart, supra note 2 at para 211; Novak, supra note 104 at para 81.

Report No 55, supra note 83 at 33. See also Report No 4, supra note 83 at 144.

Owners-Condominium Plan No 9421549 v Main Street Developments Ltd, 2004 ABQB 962, 365 AR

162 at para 63, rev'd on other grounds, 2006 ABCA 194, 384 AR 375. See also Choma (RP) Financial and Associates Inc v McDougall, 2008 ABQB 359, 451 AR 278 at para 49.

Stewart, supra note 2 at para 212, citing Novak, supra note 104 at para 85. 
counsel) and none of the Plaintiffs' claims are statute-barred. ${ }^{110}$ Even if I am wrong, the Plaintiffs' claims relating to causes of action accruing from 2003 forward nonetheless were not statute-barred. The wrongs allegedly committed by the Defendants were continuing wrongs, persisting to the date of trial. The entirety of the Plaintiffs' claims should not have been held to be statute-barred, as Justice Romaine appears to suggest. ${ }^{111}$

\section{Termination: The ShUT-IN Sub-Provisos}

Generally, the Leases were continued beyond their primary terms so long as there was production of leased substances from the Lands. Production as a condition for continuation was qualified by several provisos permitting Lease continuation despite lack of production. A subproviso permitted Lease continuation over a shut-in period, but only if the shut-in satisfied specified conditions. A separate clause provided that shut-in royalties were also to be paid, in which case the shut-in well would be deemed to be a producing well. At issue between the Plaintiffs and Defendants was a relatively narrow Lease interpretation issue focusing on whether the shut-in conditions specified in the Leases were satisfied. Two sets of Lease provisions were relevant, the southwest quarter Lease between Nellie Pole and Jefferson Lake Petrochemicals of Canada Ltd. (the Jefferson Lease), and the north parcel of the northeast quarter Lease between Jean Irwin and Union Oil Company of California (the Union Lease). ${ }^{112}$

The Jefferson Lease provided as follows:

[I]f ... any well on the said lands or the pooled lands ... is shut-in, capped, suspended or otherwise not produced as the result of a lack of or an intermittent market, or any cause whatsoever beyond the Lessee's reasonable control, the time of such interruption or suspension or non-production shall not be counted against the Lessee, anything hereinbefore contained or implied to the contrary notwithstanding. ${ }^{113}$

The parallel provision in the Union Lease provided as follows:

[I]f drilling, working or production operations are interrupted or suspended as the result of any cause whatsoever beyond the Lessee's reasonable control including, in the case of production operations, lack of or an intermittent market, the time of such interruption or suspension shall not be counted against the Lessee, anything hereinbefore contained or implied to the contrary notwithstanding. ${ }^{114}$

If the conditions in these clauses were met, the Leases would be preserved through the "time ... shall not be counted against the Lessee” language. ${ }^{115}$ Furthermore, since on the evidence the Defendants had paid shut-in royalties, if the shut-in met Lease conditions, the 7-25 Well was “deemed to be a producing well” under the Leases. ${ }^{116}$

Amoco Canada Resources Ltd v Amax Petroleum of Canada Inc, 1992 ABCA 93, [1992] 4 WWR 499 at para 15.

Stewart, supra note 2, Romaine J (“[t]he claims of the freeholder Plaintiffs in unjust enrichment, trespass and conversion are barred by the Limitations Act" at para 183).

Ibid at paras 39, 43, 46, 503. The Scurry leases had substantially similar terms, as did the lease respecting the northwest corner of the Lands.

Ibid at paras 28, 698.

Ibid at paras 32, 699.

Kissinger Petroleums Ltd v Nelson Estate (1984), 54 AR 100 at para 22 (CA), McDermid JA. Stewart, supra note 2 at para 700. 
The basic contentions of the Plaintiffs were that the Leases terminated because the conditions for shut-in of the 7-25 Well were not satisfied. There was in fact a market for the gas produced by the well. Natural gas could have been sold, even if that meant that the well would have been operated at a loss or for only nominal return. The Plaintiffs contended that the Well was shut-in not because of lack of a market, but because of the Defendants' economic priorities. Further, the shut-in was not "the result of any cause whatsoever beyond the [Defendants'] reasonable control," ${ }^{117}$ but was the result of the Defendants' decision that the 7-25 Well was insufficiently profitable. ${ }^{118}$

Six issues emerge. First, which principles of interpretation apply? Second, which general contextual features must be taken into account in interpretation? Third, does "lack of ... [a] market” mean lack of any ability to sell gas (regardless of the price or return), or lack of an economic or profitable market? Fourth, what are the interpretive effects of the language referring to "any cause whatsoever beyond the Lessee's reasonable control”? Fifth, which party bears the burden of proof on the issue of whether the evidence supported reliance on the shut-in provisions? Sixth, on the evidence, was there factual support for the Defendants' decision to shut-in the 7-25 Well?

\section{A. InTERPRETIVE PRINCIPLES}

We sometimes describe contractual interpretation as the work of discerning the parties' intentions. There's no harm in that formulation, since we ordinarily say what we mean and mean what we say - communication depends on this. Yet the focus of lease interpretation more precisely (at least in the absence of ambiguity) is on what the contract says; on what it means, not what they meant. Absent ambiguity, the contract spares us from the need to consult histories and private intentions. Contractual language and the meaning of contracts, then, enjoy a certain independence from the subjectivity of parties. It follows that the proper approach to interpretation is objective in the sense that the goal is to understand the text itself or what it would mean (objectively) to a reasonable reader. ${ }^{119}$ The "reasonable reader" is mediated by the judiciary. The recent Sattva decision has confirmed that interpretation is a legal determination of mixed fact and law. ${ }^{120}$ None of this is to say that unambiguous texts support only one more-or-less obscured meaning. Readings of a text may be contestable, and so the subject of litigation. Contestability does not entail that there cannot be better and worse readings. A job of the judiciary is to settle contested readings authoritatively.

\footnotetext{
$117 \quad$ Ibid at paras 28, 32, 698-99.

$118 \quad$ Ibid at paras 552, 559, 579.

119 Omers Energy Inc v Alberta (Energy Resources Conservation Board), 2011 ABCA 251, 340 DLR (4th) 443 at para 34, Conrad JA [Omers].

120 Supra note 41 at para 50. An implication of understanding contractual interpretation as a matter of mixed fact and law is that an appellate court must extend "deference to first instance decision-makers on points of contractual interpretation” (at para 52). The standard of review is reasonableness, unless the correctness standard is attracted (for example, in relation to constitutional questions or questions of law of central importance to the legal system as a whole); or unless an "extricable question of law" can be identified (for example, the application of an incorrect principle, the failure to consider a required element of a legal test, or a failure to consider a relevant factor) (at paras 53, 106). While Sattva concerns an arbitrator's decision, a trial judge should be entitled to at least the same level of deference as an arbitrator respecting contractual interpretation. An important practical implication for the appeal of the Stewart case is that Justice Romaine's contractual interpretations should be accorded deference by the Court of Appeal, in the absence (in particular) of an "extricable question of law."
} 
Even if meaning escapes parties' subjectivities, it is still conditioned by internal and external factors. Internally, a text must be understood as a whole. Aside from formal definition provisions, associated words and other clauses can shape the interpretation of the fragment of text in question. ${ }^{121}$ Externally, a text will be deployed in a context. It makes a difference whether a text is regarded as a shopping list, a poem, or a coded message, that is, whether it is lodged in the context of shopping, literature, or espionage. Within a context, a text will serve a purpose or set of purposes - whether it is a sale of real property, the grant of a secured interest in real property, or the grant of an oil and gas lease. Context can be both general (for example, relating to an industry) and specific (for example, the factual background to a particular transaction). ${ }^{122}$

Thus we arrive at the principles of interpretation proposed by the Court of Appeal in Omers, relied on by Justice Romaine: "The intentions of the parties are to be determined on an objective basis, what a reasonable person would infer from the words used, the agreement as a whole, the factual and legal background and the practical objectives that the contract was intended to achieve."123

For a business contract, the context-appropriate objective perspective is that of an ordinary business person, not one party or the other. Since Borys, we have understood this as the vernacular approach to understanding lease terms. ${ }^{124}$ Further, in the business context, a contract should be interpreted to support a commercially sensible result, unless express language dictates otherwise (people are free to make bad deals). ${ }^{125}$ The "should" operative here might be supported on the basis of what the parties intended; it might better be understood as a corollary of a reasonable or objective (not a strained or non-purposive) reading. Practically, a commercially sensible approach entails that a lease should be read taking into account the interests of both lessor and lessee and as benefiting both. ${ }^{126}$ Each lease, though, may strike a different balance between these interests. ${ }^{127}$

Finally, a feature of the Canadian approach to interpreting oil and gas leases is that implied terms are not read in. ${ }^{128}$ Our courts work with the terms the parties have agreed to, not those that the courts have decided that they should have agreed to. This interpretive

Omers, supra note 119 at para 33; Bearspaw Petroleum Ltd v Encana Corp, 2011 ABCA 7, 505 AR 54 at para 18 [Bearspaw]; Kensington Energy Ltd v B \& G Energy Ltd, 2008 ABCA 151, 432 AR 141 at para 13, Hunt JA [Kensington].

Nexxtep Resources Ltd v Talisman Energy Inc, 2013 ABCA 40, [2013] 9 WWR 568 at para 21 [Nexxtep]; Sattva, supra note 41 (while surrounding circumstances should be considered in interpreting contractual terms (the evidence is an "interpretive aid" for determining meaning), surrounding circumstances "must never be allowed to overwhelm the words of [an] agreement" at paras 57, 60). Stewart, supra note 2 at para 499; Omers, supra note 119 at para 34. See also Sattva, ibid at paras 48-49. Borys v CPR Co, [1953] 2 DLR 65 at 70-71 (PC), Lord Porter [Borys]; Anderson v Amoco Canada Oil and Gas, 2004 SCC 49, [2004] 3 SCR 3 at para 24, Major JA [Anderson]; Bearspaw Petroleum Ltd, Devon Canada Corp, and Fairborne Energy Ltd (28 March 2007), 2007-024, online: Alberta Energy and Utilities Board <www.aer.ca/documents/decisions/2007/2007-024.pdf >.

Omers, supra note 119 at para 78; Bearspaw, supra note 121 at para 24; Nexxtep, supra note 122 at para 34.

Nancy J Forbis, “The Shut-In Royalty Clause: Balancing the Interests of Lessors and Lessees” (1989) 67:5 Tex L Rev 1129 at 1139, 1141.

Omers, supra note 119 at para 36; Kensington, supra note 121 at para 15.

Freyberg CA, supra note 56 at para 47; Omers, ibid at para 76; Stewart, supra note 2 at para 538. 
stance is supported by the use of "entire agreement" clauses in leases, which the Leases in this action shared. ${ }^{129}$

\section{B. CONTEXT}

Some general features of the business context for shut-in clauses in classic Alberta oil and gas leases may be identified. To begin with, "the purpose and goal of parties entering into such a lease is to develop the resource for the purpose of making a profit."130 The purpose of the shut-in clause clause is to permit a lease to continue after the end of the primary term of a lease in the absence of production. The clause presupposes that a well has been completed and ordinarily that the well is capable of producing in meaningful quantities. Without the clause, the lease would terminate when production ceased. Lessees do not have the benefit of relief from forfeiture or the option of avoiding termination by paying damages. The clause, then, primarily benefits the lessee, which would lose its investment in the well if the lease terminated. That investment could be very substantial, including the costs of exploration, drilling, completion, operating the well, some processing, tying in to a pipeline, pipeline construction, and surface rentals. The clause permits the lessee to maintain its interest in the well without producing, so long as specified conditions obtain. Just which conditions are "specified" will depend on the lease.

The lessor does not have the sunk costs of the lessee, but the lessor too has significant economic interests relating to a well and the circumstances in which it may be shut-in. Notably, lessors are inclined toward encouraging production, since they stand to benefit from the resource which they entrusted to the lessee only if there is production. Otherwise, their economic interests are served by termination and the prospect of a fresh lessee paying at least a fresh lease bonus. In Freyberg, the Court of Appeal provided some reminders of lessor interests:

First, the desire by individual lessors to produce the well as soon as possible and certainly within their

lifetime is to be respected....

Second, the exigencies of the marketplace encourage production whenever it is economical and profitable....

Third, the risk of flooding increases while production is delayed.

Fourth, delayed production increases the possibility that the gas of an inactive well will be "captured" by other wells in the same formation. ${ }^{131}$ example of sample language: "The terms of this agreement constitute the entire agreement between the parties and no implied covenant or liability of any kind is created or shall arise by reason hereof or anything contained herein" (Canadian Association of Petroleum Landmen, CAPL 2012 Form: Petroleum and Natural Gas Lease and Grant, online: CAPL <www.landman.ca/pdf/2012/CAPL\%202012\%20 Draft\%20Freehold\%20P\&NG\%20Lease.pdf $>$ ).

$131 \quad$ Freyberg CA, supra note 56 at paras 50-53. See also Bearspaw, supra note 121 at para 28. 


\section{LACK OF A MARKET}

The Jefferson Lease provided that "if ... any well ... is shut-in, capped, suspended or otherwise not produced as the result of a lack of ... [a] market ... the time of such interruption or suspension or non-production shall not be counted against the Lessee.”132 The Union Lease provided that "if ... production operations are interrupted or suspended as the result of ... [the] lack of ... [a] market, the time of such interruption or suspension shall not be counted against the Lessee." ${ }^{133}$ How is the phrase "lack of a market" to be understood in these clauses? Is it equivalent to the phrase "lack of an ability to sell gas, regardless of price" or "lack of an ability to sell gas, at a fair price"? Properly speaking, this is not a dispute between a literal interpretation and some sort of expansive interpretation. It is a dispute between two different literal interpretations. At issue is what the words mean. The Defendants were not seeking to rely on implied terms, but on the meaning of the Leases, read in context - that is, they relied on what the Leases did say, not what they did not. The challenge is to arrive at an interpretation that is reasonable and does not unduly favour one party over the other, determined with reference to the agreement as a whole and its commercial context.

Some applications and non-applications of "lack of a market” language are clear enough. We would not say that a well was shut-in because of a "lack of a market" if the reason for the shut-in were the lack of natural gas in meaningful quantities. The reason for the lack of production would be the lack of production, not the "lack of a market." The 7-25 Well, in fact, was capable of production and had been productive, even if it was in decline. ${ }^{134}$ In contrast, we would say that a well was shut-in because of a "lack of a market" if a well were capable of producing natural gas, but the gas were for example, extremely toxic, there were no way to render it less harmful, and it could not be sold in its unprocessed state. There would be "a lack of a market" in the sense that no one would buy it. Further, there would be a "lack of a market" if a well were capable of producing gas which could be processed and sold, but there were no pipeline system to convey the gas to purchasers. There would be "a lack of a market" in the sense that no one would buy what they could not physically acquire. Finally, there would be a "lack of a market" if, for example, government regulation forbade sale. In this case, there would be no purchasers.

One might argue, then, that if a well is capable of production, the gas can be put into saleable form, the product can be conveyed to purchasers, and potential purchasers exist, there is a market and it cannot properly be said that there is a "lack of a market." Put another way, a market requires marketable goods, a means to transfer possession, and willing purchasers. On this approach, as argued by the Plaintiffs, a lessee's profit margins are irrelevant to the application of the "lack of a market" language. If there is a market (product, access, purchasers), a lessee is obliged to sell, even at a loss. Failure to sell in the presence of a market means the lease is lost. 
This interpretation has some contextual support, identified in the Kansas jurisprudence:

\begin{abstract}
The shut-in royalty clause was developed to protect against automatic termination of a lease where a gas well was drilled and no market existed for that gas. The reason that the shut-in royalty clause has come into growing use goes back to the inherent physical nature of natural gas. Unlike oil, it cannot be produced and stored or transported in railroad cars or tank trucks. A lessee completing a gas well consequently often had a special and quite onerous problem in finding a market outlet for the gas production. This would, at times, result in losing a lease at the end of the primary term.
\end{abstract}

The "shut-in" royalty clause applies to circumstances where "a well capable of producing a profit is drilled but for the time being no market exists.” There is a mutual interest between the lessor and lessee when no market for the gas exists. However, once a market for gas is secured, that mutual interest no longer exists because the lessor's interest is in securing royalty payments from production, while the lessee's interest is divided between receiving revenues and minimizing expenses associated with that production. Thus, the "shut-in" royalty clause serves the interests of both parties only in situations where no market exists for the gas. $^{135}$

This interpretation has some textual support, which yields a strong argument. The Plaintiffs drew attention to the "Offset Well” clauses in the Leases, which provided that certain Lessee offset well obligations "could be postponed pending the establishment of 'an adequate and commercially profitable market.",136 If the "lack of a market” language were meant to be economically qualified, the parties could have said so, and the failure to have said so, given the express contrast in language, entails that the two sets of provisions have different meanings (otherwise they would have used the same language). ${ }^{137}$ The Plaintiffs could have drawn attention to shut-in clauses like the one litigated in Freyberg, which expressly referred to the absence of an "economical or profitable" market. ${ }^{138}$ Those three words could easily have been added in to the clause in question. Again, it is the deal made that is in question, not the deal that should have been made or that would have been made had the lessee been more careful.

Justice Romaine dismissed the Offset Well clause argument swiftly: “As the Defendants note, the offset well provisions of the leases have a completely different specific function that

Tucker v Hugoton Energy Corp, 855 P (2d) 929 at 936 (Kan 1993), Lockett J [Tucker] [citations omitted, emphasis in original]. Later authority, however, disputes the cogency of the reasoning in Tucker. See Levin v Maw Oil \& Gas LLC and Clary Energy LLC, 234 P (3d) 805 at 818 (Kan 2010), Beier J.

Although Tucker asserts that the total absence of a market for natural gas is a prerequisite to classify a well as shut-in and thus bring into play a shut-in royalty clause, this assertion appears to arise out of an overinterpretation of Pray and insufficient attention to the subject leases' language. The presence or absence of a market and its prospects for a lessee's ability to turn a profit may be made pertinent to interpretation and application of a shut-in royalty clause because of the lease's language, but it is not inevitably relevant as a matter of law. In other words, Pray did not make the absence of a market a part of Kansas' definition of "shut-in." Such a consideration is, on the other hand, indispensable to analysis of whether a lessee has discharged its duty under the covenant to produce and market. The covenant is not before us here. conclusions were not reasonable: see Newfoundland and Labrador Nurses' Union v Newfoundland and Labrador (Treasury Board), 2011 SCC 62, [2011] 3 SCR 708, Abella JA ("even if the reasons in fact given do not seem wholly adequate to support the decision, the court must first seek to supplement them before it seeks to subvert them" at para 12 [emphasis omitted]). 
is not comparable to the habendum clause and its provisos."139 It is true that the two sets of provisions have different functions: the former to preserve the lease in the absence of production, and the latter to provide options to a lessee in the event of competitive drainage by a "robber" well. That observation, though, does not settle the interpretive point: what should be made of the different language in the two lease provisions? Why should we interpret "market” the same way as "an adequate and commercially profitable market”?

The Defendants would argue that the differences in language amount to nothing. The Lease does qualify the term "market" in the Offset Well clause. But that does not entail that the shut-in clause must be interpreted as referring to an "uneconomical" or "economical or uneconomical" market. If qualifiers of "market" had been intended in the shut-in clause, these qualifiers could have been expressly stated. Interpreting "market" in the shut-in clause as an "uneconomical" or as "even an uneconomical" market is as much or more of a supplementation as interpreting market as an "economical” market. The Defendants could also have argued that the Offset Well clause's "adequate and commercially profitable” language is redundant, or was used out of an abundance of caution. The "adequate and commercially profitable” qualifications are implicit in the notion of a "market," properly understood.

The difficulty is that the Plaintiffs' interpretation of "market” is incomplete. A market does require product, access to the product, and purchasers, but it also requires a vendor a willing vendor. If a vendor were not willing, we would not refer to a sale as a "market" transaction. The sale would not be "for market value" because it would not be a sale on the "market." For example, in the foreclosure context, we would refer to values for court-ordered sales as "forced sales" or "forced sales on terms," distinguishing the amounts to be received from those generated from market transactions. ${ }^{140} \mathrm{~A}$ vendor would be willing only if a profit were to be made (over some time-frame). This is consistent with a purpose of a lease, which is to permit both the lessor and the lessee to make money. Further, developing oil and gas resources is an expensive business. Lessees must sink substantial capital to establish wells capable of production. It would not make commercial sense to prevent lessees from managing their ongoing expenses. Put another way, the difficulty with the Plaintiffs' argument is that it reads out lessee interests in understanding the meaning of the term "market." The purpose of a lease is to permit both parties to profit, not to compel one party to operate at a loss. ${ }^{141}$

Moreover, interpreting a lease to require production in the absence of an economical market may not serve lessors' interests. The royalty provisions under the Leases are not discussed in the case, but presumably the Defendants could deduct post-wellhead costs from royalties payable. If, for example, the price of gas were low and the price of processing and transportation were high, there could be little left for a lessor, perhaps not much more than the shut-in royalty amount. 
Another consideration is that a lessor receives a royalty under a lease, not a fixed income stream (come what may). If there is production, depending on the amounts, the costs of production, processing, transportation, and the price of natural gas, the lessor gets its share. Variability of returns, turning in part on the operation of markets, is an inherent feature of a royalty interest; variability of returns is inherently within the reasonable contemplation of parties to leases. It is not simply “the lessee’s problem” if the market collapses, such that the lessor gets paid, regardless. The purpose of the royalty provisions is not to put all risk of market fluctuation on the lessee. ${ }^{142}$

If a willing vendor is required to constitute a "market," the Defendants' interpretation is supported. This approach would not leave lessors at the mercy of lessees' idiosyncratic profit ambitions. An economical market is not one that is economical only from the perspective of a particular lessee, even a good faith lessee ("an honest lessee who has considered all the material factors”). ${ }^{143}$ Recall that the lease must be interpreted objectively. An economic market is one that would be economic to a reasonable lessee, in the position of the lessee in question, that is, to a similarly situated lessee, or to a lessee in the relevant circumstances: "The test to be applied is whether, based on information available at the time, a prudent lessee would have foreseen profitability." 144 The reference to the "position" or "circumstances" of the lessee is important. The price of natural gas or the availability of potential purchasers in the abstract cannot determine whether the production of a particular well makes economic sense. Factors relevant to a particular well, its operational requirements, and the available transmission and processing system should be considered when assessing what a reasonable lessee would do.

One might suggest that the interpretive issues at work in this case are similar to or are the mirror image of the interpretive issues in Omers. In that case, the lessee (not the lessor) urged a reductionist (literal) interpretation of the lease: “'capable of producing' for the purposes of the OMERS Lease [means] whenever it has the ability to achieve any production flow whatsoever." "145 The lessee opposed a reading of the lease that imported an economic "producing in commercial or paying quantities" interpretation of "capable of production." As in Stewart, in contrast to the shut-in clause, the Omers offset clause used a "commercial quantities" modifier of production. ${ }^{146}$ As in Stewart, in contrast to the lease under consideration, other leases were referred to which expressly qualified the term "production" in shut-in clauses with "commercial" modifiers. ${ }^{147}$ While the Court of Appeal was not prepared to read in words which the parties had not chosen, it interpreted "capable of producing" in a purposive, normative manner: "When dealing with the interpretation of 'capable of producing the leased substances', the Board correctly found two factors must be satisfied. First, the well had to be capable of producing and, second, it had to be capable of producing the resource in a meaningful quantity." 148 That approach made sense given the

In contrast, under a long-term gas purchase contract, a vendor's manifest purpose may be to protect itself against changes in market prices. That is why it locks in a price. The risk of a downturn would be properly borne by the purchaser. See Michelle P Theroux \& April D Grosse, "Force Majeure in Canadian Law" (2011) 49:2 Alta L Rev 397 at 412. Freyberg CA, supra note 56 at para 71.

Ibid at para 72 .

Omers, supra note 119 at para 48, citing the Factum of the Appellant at 40.

Ibid at paras 72-73.

Ibid at para 53.

Ibid at para 80 [emphasis omitted]. 
mutual profit motives of the parties. ${ }^{149}$ So too in this case, interpreting "market" in a purposive, normative manner, with due regard to the profit motives of both lessor and lessee, also makes sense. Finally, one might understand this case as taking up a doubly-qualified invitation from Omers (a passage dealing with different lease language and not part of the ratio of the case):

Unlike some Canadian oil and gas leases, the Cymbaluk Lease does not (apart from the Force Majeure Clause) describe when shut-in may occur. The Suspended Wells Clause deals only with the consequences of a suspended or shut-in well that is "capable of producing the leased substances”. There may be many valid reasons to shut-in a well. For example, there may be no market for gas during certain months, or quota may have been reached. Although the Board seemed to accept that a well capable of production would be shut-in for a valid reason - seemingly a reasonable assumption having regard to the terms of the lease and the desirability of capturing gas while capture is possible - none of the parties to this appeal challenged the right to shut-in a well for any reason whatsoever. As the issue of entitlement to shut-in is not directly engaged in this appeal, I leave to another day the question of whether the language of this lease, viewed objectively, demonstrates a common intention that a well, even one "capable of producing", can only be shut-in for prudent reasons. $^{150}$

"Prudent reasons" could well be understood as reasons that would motivate a "prudent lessee."

We therefore arrive at Justice Romaine's conclusion: "I find that the phrase 'lack of or an intermittent market', read in context and with a view to the reasonable intention of parties to a lease to profit from the extraction of leased substances, should be interpreted to mean lack of or an intermittent economical or profitable market."151

\section{CAUSE BEyOND THE LESSEE’s REASONABLE CONTROL}

The Jefferson Lease provided that "if ... any well on the said lands or the pooled lands ... is shut-in ... as the result of a lack of or an intermittent market, or any cause whatsoever beyond the Lessee's reasonable control, the time of such interruption or suspension or nonproduction shall not be counted against the Lessee."152 Under the parallel provision in the Union Lease, "if ... production operations are ... suspended as the result of any cause whatsoever beyond the Lessee's reasonable control including, in the case of production operations, lack of or an intermittent market, the time of such interruption or suspension shall

Ibid at para 62.

Ibid at para 46. See also Alicia Quesnel \& Aaron Rogers, “Assessment and Analysis of the Decision of the Alberta Court of Appeal in OMERS Energy v Alberta (Energy Resources Conservation Board)” (2012) 50:2 Alta L Rev 337 at 359.

Stewart, supra note 2 at para 542. Simard, Holub, and Taylor rightly point out that the challenges in applying this sort of lease language are different than those dealt with in numerous Canadian lease termination cases (for example, whether production occurred before the "click date"; whether delay rentals were paid on time and to the right person; whether "operations" had commenced prior to the click date). In these sorts of cases "any party, or a court, can accurately determine whether or not those preconditions to lease validity existed"; in shut-in cases turning on well economics, whether the facts entail lease termination "is a matter of opinion on which different parties (and different judges) may have different opinions” (Chris Simard, David Holub \& Larina Taylor, "Lady Freyberg: Examples of How Contemporary Courts in Alberta Approach the Modern Business Realities of the Freehold Petroleum and Natural Gas Lease” (2009) 46:2 Alta L Rev 299 at 310). Stewart, supra note 2 at para 28 [emphasis added]. 
not be counted against the Lessee." "153 Justice Romaine correctly observed that the "lack of a market” language does not exist in isolation. Its meaning is coloured by the "cause beyond the Lessee's reasonable control" language. In the Jefferson Lease, "cause beyond the Lessee's reasonable control" is an alternative to the lack of a market. One might read the disjunction in two different ways. On the one hand, the alternative "cause" may be different in type than the preceding disjunct. On the other hand, the alternative "cause" may be of the same type as the preceding disjunct, so that a "lack of a market" would be one instance of "a cause beyond the Lessee's reasonable control.” The latter approach favours the Plaintiff. If “cause beyond the Lessee’s reasonable control” has a restricted or restrictive meaning, on this approach, the "market” language should be interpreted restrictively. The Union Lease more clearly supports the Plaintiffs' approach, since lack of a market is an example of a "cause beyond the Lessee's reasonable control." ${ }^{54}$ How then is the "cause beyond reasonable control” language to be interpreted?

The Plaintiffs urged a force majeure interpretation of this language: a cause beyond reasonable control is an external event over which a Lessee exercises no practical control. The event makes performance practically impossible. No element of Lessee assessment and choice is relevant to constitute the cause. A cause beyond reasonable control, then, would include an absence of any market, but would not include a merely uneconomical market. ${ }^{155}$

The Plaintiffs' interpretation faced numerous difficulties. First, the very language referred to "causes beyond the Lessee's reasonable control." This language would include causes entirely beyond the Lessee's control, but the phrase includes more; it includes causes that are beyond the Lessee's reasonable ability to influence, manage, mitigate, or avoid. In this case, the events that led to the shut-in (as will be seen below) were "a drastic down-turn in the price of gas and accompanying high processing costs caused by external forces." 156 These factors were not within the Defendants' reasonable control. That is, even on a force majeure interpretation, the conditions for application of the clause were satisfied. Second, the interpretation of the "cause beyond reasonable control” language is not coloured by the inclusion of restrictive, external cause examples, such as “act[s] of God, the Queen's or public enemies, war, the authority of the law, labour unrest or strikes, [or] the destruction of or damage to production facilities," 157 a list of "supernatural events beyond the control of either party." "158 Third, the Union Lease contained a force majeure clause that included "act of God"-style language. The purpose of that clause was to measure whether or not the Lessee would be in default of its contractual obligations: "The office of the clause is to protect the parties from events outside normal business risk." 159 In contrast, the shut-in provisions concern the different issue of whether the Leases continue, despite the lack of production.

\footnotetext{
$153 \quad$ Ibid at para 32 [emphasis added].

Ibid at para 541 .

Ibid at paras 544-48.

Ibid at para 558 .

Ibid at para 545, citing Atlantic Paper Stock Ltd v St Anne-Nackawic Pulp \& Paper Co (1975), [1976] 1 SCR 580 at 582.

Stewart, ibid at 549. See also Theroux \& Grosse, supra note 142 at 406.

159 Atcor Ltd $v$ Continental Energy Marketing Ltd, [1996] 6 WWR 274 at para 12 (Alta CA), Kerans JA; Theroux \& Grosse, ibid at 398, 401.
} 
The Defendants are under no contractual obligation to continue production or to preserve the Leases (they have a privilege or choice). ${ }^{160}$ Thus, Justice Romaine correctly concluded that

it is not necessary to interpret the phrase "any cause whatsoever beyond the Lessee's reasonable control" in such a manner as to restrict it to events of an "act of God" or "supervening sometimes supernatural” nature that make performance impossible. The Third Proviso language is not a true force majeure provision, and there is no reason to imply the limitations suggested by the Plaintiffs. No absurdity arises in giving the phrase its ordinary meaning. ${ }^{161}$

To the extent that the "any cause beyond the Lessee's reasonable control” language colours the interpretation of "market," it supports the view that a "lack of a market" is a lack of a reasonable market. A reasonable market is one in which a reasonable lessee would sell natural gas. A reasonable lessee would not sell at a loss.

\section{E. Burden of Proof}

The general principles relating to the burden of proof are established:

In a civil case, the two broad principles are:

1. that the onus is on the party who asserts a proposition, usually the plaintiff;

2. that where the subject matter of the allegation lies particularly within the knowledge of one party, that party may be required to prove it. ${ }^{162}$

From one perspective, the allocation of the burden of proof in shut-in cases was settled by the Court of Appeal in Freyberg. A lessor discharges its burden by establishing that a lease existed and it was carried past the primary term by production, but production ceased in the secondary term. ${ }^{163}$ The lessee, then, has the burden of demonstrating that, on the evidence, the failure to produce did not result in the termination of the lease. ${ }^{164}$ The lessee must show that, given the proper interpretation of the clause on which it relies to avoid lease termination, the evidence supported reliance on that clause. These propositions derive from Freyberg, "even though [the defendants] never alleged that such a market existed [and the plaintiff lessor did], and even though they had no better access to the facts surrounding market conditions than did the plaintiff lessor." ${ }^{165}$ Regardless, on the Freyberg approach, in this case the Defendants had the burden of establishing that there was a lack of a market for the gas producible by the 7-25 Well or that the 7-25 Well could not be produced, for reasons beyond the Defendants' control. Justice Romaine followed the lead of the Court of Appeal, justifiably. There was no suggestion that at the material times the Plaintiffs had access to

Stewart, supra note 2 at para 550; Freyberg CA, supra note 56 at para 58; Quesnel \& Rogers, supra note 150 at 361.

Stewart, ibid at para 553.

Snell v Farrell, [1990] 2 SCR 311 at 321, Sopinka JA, cited in Freyberg CA, supra note 56 at para 75. See also Stewart Estate v TAQA North Ltd, 2012 ABQB 87, 77 Alta LR (5th) 208 at paras 13-14, Romaine J [Stewart Interlocutory].

Freyberg CA, ibid at para 76.

Ibid at paras 75-82; 549767 Alberta Ltd v Teg Holdings Ltd, [1997] AJ No 321 (QL) at para 4 (QB) [Teg Holdings].

Simard, Holub \& Taylor, supra note 151 at 308. 
information concerning the circumstances of the 7-25 Well equivalent to or better than the Defendants.

Stewart is distinguishable from two prior shut-in cases on burden of proof grounds. In Blair Estate, the respondent sought to justify shut-in "because of lack of market, or of an intermittent market or for some other cause beyond the respondent's control.”166 The respondent failed to discharge its burden of proof (which, by implication, lay on it as lessee):

The evidence adduced by the respondent supported the inference that insofar as its major customer. TransCanada Pipelines was concerned, the market was intermittent. However there was also evidence of a different potential market described as being “discount commercial markets”. In our view the evidence did not demonstrate a lack of such an alternate market. Accordingly, the respondent did not prove that there was a lack of market for the natural gas product in order to trigger the extension of the primary term of the lease. ${ }^{167}$

In Teg Holdings, the evidence disclosed that at the material times, the wells were commercially viable, transportation and processing was available, and there were markets for the gas (both direct and interruptible or spot-sales). ${ }^{168}$ A dispute with the pipeline operator respecting the costs and location of a compressor that would be necessary to tie-in the wells to the pipeline system did not eliminate the availability of transportation, particularly because the lessee could make an application for a common carrier order, compelling the operator to carry the lessee's gas. On the evidence in Stewart, the 7-25 Well was capable of production, and transportation and processing facilities were available or potentially available. Justice Romaine found, however, on the basis of the evidence reviewed in the next section, that the Defendants had established that there was no "market" for the gas that could have been produced from the 7-25 Well.

\section{F. EVIDENCE SUPPORTING SHUT-IN}

Significant lay evidence was tendered by the Defendants on the issue of whether the 7-25 Well was shut-in because it was uneconomical to continue production in July $1995 .{ }^{169}$ Both the Plaintiffs and Defendants tendered expert evidence on the issues of whether "the decision to shut-in the well was appropriate, and whether a prudent lessee would have foreseen profitability during the shut-in period." " expert evidence should be noted.

First, Justice Romaine found that in this case, in contrast to the Court of Appeal's finding in Freyberg, the expert evidence was admissible. Expert evidence is admissible if the evidence is relevant, necessary, reliable, and not excluded by any other admissibility rule. The witness who is to provide the evidence must also be qualified. ${ }^{171}$ The Freyberg problem

Blair Estate Ltd v Altana Exploration Co, [1987] AJ No 554 (QL) at para 1 (CA), Irving JA.

Ibid at para 3.

Teg Holdings, supra note 164.

Stewart, supra note 2 at para 352.

Ibid. Justice Romaine dealt with two sets of expert evidence issues falling under rule 5.35 (respecting the admissibility of expert evidence) and rule 9.13 (respecting re-opening a case in the Stewart Interlocutory decision (supra note 162).

David M Paciocco \& Lee Stuesser, The Law of Evidence, 6th ed (Toronto: Irwin Law, 2011) at 190; Bryant, Lederman \& Fuerst, supra note 31 at 791; Freyberg CA, supra note 56 at paras 85-86; $R v$ Mohan, [1994] 2 SCR 9 at 23-25, Sopinka JA. 
turned on the necessity criterion. Necessity has two aspects. On the one hand, it has a policy aspect: expert evidence is not admissible, for example, on the issue of whether a witness is telling the truth. That is a matter that is left to the lay competence of the trier of fact. On the other hand, necessity has a reasoning aspect: expert evidence must be necessary in the sense that it provides inferences or perspectives on the evidence that lay common sense cannot supply. ${ }^{172}$ According to Justice Dickson in Abbey:

With respect to matters calling for special knowledge, an expert in the field may draw inferences and state his opinion. An expert's function is precisely this: to provide the judge and jury with a ready-made inference which the judge and jury, due to the technical nature of the facts, are unable to formulate. "An expert's opinion is admissible to furnish the Court with scientific information which is likely to be outside the experience and knowledge of a judge or jury. If on the proven facts a judge or jury can form their own conclusions without help, then the opinion of the expert is unnecessary."173

In Freyberg, the Court of Appeal was of the view that expert evidence was not necessary on the issue of whether the shut-in was caused by a lack of an economical or profitable market. The facts-in-issue could be addressed through lay or non-expert common sense. ${ }^{174}$ In that case, the presence of an economic market could be inferred from the conduct of the defendant Voyager. During the period in which the plaintiff's well was shut-in, the defendant produced from neighboring wells that produced from the same formation. Those other wells bore higher expenses, and the shut-in well was in a geologically superior location and had greater production prospects than the wells actually produced. ${ }^{175}$ In contrast, in the case before Justice Romaine, whether or not there was an economical market for the shut-in gas was not apparent to the non-expert eye. ${ }^{176}$ Expert evidence was necessary.

Second, Justice Romaine attached greater weight to the experts called by the Defendants than to those called by the Plaintiffs. A key factor in her appraisal was that the Defendants' experts were independent while the Plaintiffs' experts were not, they had occupational ties to the Plaintiffs. ${ }^{177}$ Independence goes to the assessments of the weight of evidence and to the admissibility of expert evidence. Justice Romaine followed the approach of our Court of Appeal, which has held that lack of independence goes to weight, not admissibility. ${ }^{178}$ It appears that in this case, there was no attempt to disqualify an expert on lack of independence grounds. The Supreme Court has recently confirmed that lack of independence, rendering a witness unable or unwilling to provide fair, objective, and non-partisan evidence, prevents the witness from testifying as an expert; his or her opinion evidence would be inadmissible. $^{179}$

Despite the volume of lay and expert evidence (reviewed by Justice Romaine over some 270 paragraphs), the circumstances surrounding the shut-in of the 7-25 Well were

\footnotetext{
172 Bryant, Lederman \& Fuerst, ibid at 785-86, 796-800.

$173 \quad R$ v Abbey, [1982] 2 SCR 24 at 42 [citations omitted].

$174 \quad$ Freyberg CA, supra note 56 at para 87. See also Simard, Holub \& Taylor, supra note 151 at 313.

$175 \quad$ Freyberg CA, ibid at para 88.

176 Stewart, supra note 2 at paras 351-53.

$177 \quad$ Ibid at paras 373, 396, 487.

$178 \quad$ Ibid at para 371 [citation omitted].

179 White Burgess Langille Inman v Abbott and Haliburton Co, 2015 SCC 23, 383 DLR (4th) 429 at paras
} $2,46$. 
straightforward, if unfortunate. During the shut-in period, the price of gas was low, processing costs for the 7-25 Well gas were high, sulphur produced along with gas ${ }^{180}$ was a liability rather than an asset, ${ }^{181}$ production volume was subject to significant shrinkage because of the co-production of sulphur and carbon dioxide, ${ }^{182}$ few natural gas liquids (which would have added value) were produced along with the natural gas, and the processing plant for the 7-25 Well gas had only very limited capacity to capture natural gas liquids. Thus, the "cumulative cash flow from the [7-25 Well] was negative and it was producing at a loss."183 The Well required reworking to enhance production, but there was no reasonable prospect that the investment required for reworking would be paid back through production revenues. The quantity of production from the 7-25 Well was in decline. ${ }^{184}$

The central problem besetting the 7-25 Well was location, which exposed it to three adverse impacts. First, the 7-25 Well was located in the territory of a competitor, Amoco. The well was subject to significant competitive drainage. Amoco had a lot of "straws" in the target formation. ${ }^{185}$ Second, processing costs were high not only because of the sulphur content of the gas but because the Defendants did not have an ownership interest in the plant that processed 7-25 Well gas. The plant was operated by Amoco, which was not cooperative. The Defendants had to pay a third-party access mark-up for processing at the plant. ${ }^{186}$ At one point in the late 1970s the Defendants had planned to bring a "common processor" application respecting the plant, but that plan was abandoned, apparently because the plant was operating at capacity. ${ }^{187}$ Access was eventually negotiated.

Third, the 7-25 Well's location prevented it from obtaining access to another processing plant, the Petrogas Plant, in which the Defendants did have ownership interests. The Defendants operated some nearby wells producing from the Crossfield formation that produced more than the 7-25 Well. ${ }^{188}$ The 7-25 Well, though, was located on the west side of Highway 2. The other wells and the Petrogas Plant were located on the east side. There was no pipeline beneath Highway 2 permitting the 7-25 Well to tie into the east-side network. The Defendants did consider bringing an application to construct such a pipeline to the (then) Energy Resources Conservation Board (ERCB). The sulphur content of the gas added complexity. The City of Calgary was expanding towards the gas production areas. Given the high toxicity of the gas, there were significant concerns about health effects should a blow-out occur. The ERCB was contemplating holding a public hearing respecting development in the entire area. The 7-25 Well pipeline application would have been woven into that hearing. The industry consensus was that if the ERCB went ahead with a hearing, it was likely that the Petrogas Plant would be shut down. ${ }^{189}$ Gas production in the area would be the casualty. The Defendants did have "east-side" interests at stake, but the anticipated consequences of a public hearing would occur regardless of the Defendants' ownership position. A Highway 2 crossing application would not have made sense even if all of the

The 7-25 Well gas was very sour: see Stewart, supra note 2 at paras 13, 230, 438, 440.

Ibid at paras 437, 567. See also 262, 272, 405, 434.

Ibid at paras 255, 406, 436.

Ibid at para 567.

Ibid at paras 275, 567.

Ibid at paras 273, 278.

Ibid at paras 236, 238, 252, 259, 273, 564.

Ibid at paras 243-44, 323.

Ibid at paras 231, 237, 562.

Ibid at paras 305, 310-11, 314, 562. 
Defendants were entirely independent from east-side operations. ${ }^{190}$ Thus, the pipeline application did not proceed and the 7-25 Well was left with its unfavourable west-side processing.

The evidence relating to the 7-25 Well and its location allowed Justice Romaine to conclude that the economic circumstances of the 7-25 Well were not the result of any unfair conduct by the Defendants. ${ }^{191}$ The factors negatively affecting production decisions were outside the control of the Defendants. Compelling production at a loss would not be reasonable. Justice Romaine therefore found that

[t]he Defendants have met their onus of establishing on a balance of probabilities that the 7-25 Well was shut-in for reasons that fell within the ameliorating provisions of the Third Provisos of the leases, and the leases thus did not terminate as a result of the lack of production from August 1995 until January 20, $2001{ }^{192}$

She stated:

[T]hus, I accept that the 7-25 Well was shut-in in July, 1995 for causes beyond the [Defendants'] reasonable control, in that it was uneconomical to produce during the shut-in period given the low price of gas and the relatively high costs of production and processing, effectively a lack of an economic market. ${ }^{193}$

\section{Causes of Action AND Damages}

Justice Romaine went on to consider liability and damages issues, should she be found to have erred in finding that the Leases did not terminate. Lease termination would have occurred in or about 1995, when the 7-25 Well was shut-in. The Defendants remained on the Lands and produced natural gas from 2001 to 2011, when the 7-25 Well went back into production following recompletion in the Basal Quartz formation. The Defendants profited. Gross revenues were about \$31.5 million and net operating income was about \$23.6 million. ${ }^{194}$ Royalties were paid to the Plaintiffs. Two linked sets of issues arise: what cause or causes of action would be available to the Plaintiffs?; and, if a cause of action were made out, what would be the appropriate measure of damages? Justice Romaine's reasons were brisk, but arrived at the right conclusions. To avoid confusions in remedies and theory as between restitution in torts cases and restitutionary relief in (true) unjust enrichment cases, I will consider (1) the torts claims then (2) the claim in unjust enrichment. It will be seen that regardless of the route, in this case the Plaintiffs' damages would be calculated in a similar manner.

$191 \quad$ Ibid at para 563.

The Plaintiffs position respecting the history of the 7-25 Well, the events which formed the setting for the 1995-2001 shut-in, was not completely clear (the evidence was said to be relevant to damages (ibid at para 219), but if the Lessees had manipulated events to shut-in the 7-25 Well, it is conceivable that the plaintiffs could have claimed damages for breach of duty of good faith: see Erehwon Exploration Ltd v Northstar Energy Corp (1993), [1994] 3 WWR 488 at para 148 (Alta QB).

192 Stewart, supra note 2 at para 579.

$193 \quad$ Ibid at para 568.

Ibid at para 581. 


\section{A. Causes of Action in Tort}

Ex hypothesi, the Defendants remained on the Lands and produced after the Leases had terminated, that is, after their authorization had ended. They were doing what they were no longer entitled to do. The Plaintiffs claimed trespass and conversion. ${ }^{195}$ There were serious obstacles to finding that those causes of action were established.

\section{TRESPASS}

\section{Trespass is}

the direct, intentional (or negligent), and physical interference with land in the possession of the plaintiff. It is actionable without proof of damage. Trespass to land is committed in three ways. First, and most commonly, it is a trespass to enter personally onto land in possession of the plaintiff without permission.... Second, it is a trespass to place objects on the plaintiff's property... Third, a trespass may arise when the possessor revokes a visitor's permission or licence to be on the property. If the visitor does not leave the property within a reasonable time, he becomes a trespasser. ${ }^{196}$

The Defendants might be thought to have committed the third type of trespass, assuming Lease termination. Their permission or licence to be on the Lands ended. The trespass argument, though, faced some challenges.

First, there was no indication that the Defendants' surface rights terminated along with the Leases. If surface rights did not terminate, the trespass could only be to the Plaintiffs' mines and minerals rights. There is an issue as to whether freehold ownership of mines and minerals rights (alone) supports an action in trespass. This issue goes to the nature of mines and minerals ownership in Canada, which, remarkably, has not yet been authoritatively settled:

The appellants submitted that Canada is not an ownership in situ jurisdiction and therefore no rights vest in hydrocarbons until they are reduced to possession. They relied on this ownership theory as support for their position that it is not until the time of possession that the phase of the hydrocarbon becomes important for determining ownership, because no one has any rights before that. This is the type of broad ownership theory that is not required to be determined in this appeal. Irrespective of any other rights the parties may have in relation to the hydrocarbons in the ground, they chose to divide their interest by contract. It is not open to later argue that division was meaningless on the basis that no rights can attach until the substance is reduced to possession. When the substance, which was not in their possession at the time of the contract, is reduced to possession, the date and terms of the contract govern their relative entitlement. ${ }^{197}$

Ibid at para 584 .

Philip H Osborne, The Law of Torts, 4th ed (Toronto: Irwin Law, 2011) at 294-95. See also Klar, supra note 88 ("a trespass occurs if a person, who is on land lawfully, refuses to leave once asked to do so" at 116).

Anderson, supra note 124 at para 36. In contrast to the freehold position, the Province as mines and minerals owner can rely on a statutory trespass cause of action: Mines and Minerals Act, RSA 2000, c M-17, ss 54-57. See also Alberta, Department of Energy, “Alberta's Oil and Gas Tenure," currently being updated (Edmonton: Department of Energy, September 2009) at 22, online:<www.energy.alberta. ca/Tenure/pdfs/tenure_brochure.pdf > . 
Trespass protects possession. If a mines and minerals owner does not have possession, but only a right of possession, an action in trespass could not be supported. However, in support of the availability of trespass, it appears that a mines and minerals owner could enjoy a form of deemed possession:

[A]ll land in the dominions of the Crown must be in the possession of some one, whether that "some one" be the Crown itself or a natural or artificial entity. "Vacant" land — "abandoned" land, (where title is involved) is an impossibility. Possession must be somewhere — in somebody — and he who has the title is presumed to have the possession unless the actual dominion and occupancy is elsewhere. ${ }^{198}$

Alternatively, through the exercise of control over the mines and minerals, such as by granting a lease, possession could be manifested. ${ }^{199}$ Furthermore, given that a profit à prendre in the form of oil and gas lease rights supports an action in trespass, the superior estate of the lessor from which the profit à prendre is derived ought to support an action in trespass. ${ }^{200}$ If the Plaintiffs' mines and minerals rights supported trespass, presumably the interference with those rights occurred only during the period of production from 2001 to 2011.

Second, the 7-25 Well was located on the southeast quarter section of the Lands, that is, Lands owned by the Jerome Group Plaintiffs. Justice Romaine, however, had found that a declaration respecting the Scurry Leases could not be granted. If the Scurry Lease on the southeast quarter section had not (could not be found to have) terminated, the Defendants could not have been trespassing on those lands. ${ }^{201}$

Third, even if the Scurry Lease (and the southeast quarter section surface lease) terminated, neither the Plaintiffs nor the Defendants were aware of this until, at the earliest, about August 2003 (the dispute between the Plaintiffs and Defendants manifested between 2003 and 2005). ${ }^{202}$ The Defendants' permission to be on the Lands was not revoked until about September 2005 when they were served with Notices to Vacate. ${ }^{203}$ Until that time, then, it is arguable that the Defendants were not trespassing. ${ }^{204}$ As Nigel Bankes has pointed out, mere overholding by a tenant or lessee, prior to revocation of permission to be on the lands, does not support trespass. ${ }^{205}$ It is true that an oil and gas lease is not treated as a surface-based landlord and tenant lease for all purposes. ${ }^{206}$ That observation, though, does not settle the question of whether for the purposes of trespass an oil and gas lease relationship should be treated similarly to or differently than a traditional lease, particularly

Bentley v Peppard (1903), 33 SCR 444 at 445, Sedgewick JA. See also William Blackstone, Commentaries on the Laws of England, 1st ed (Oxford: Clarendon Press, 1766) vol 2 ("the word 'land' includes not only the face of the earth, but everything under it, or over it” at 16), cited in Klar, supra note 88 at 117 .

Klar, ibid at 113-14

Xerex Exploration Ltd v Petro-Canada, 2005 ABCA 224, 256 DLR (4th) 218 at paras 85-86 [Xerex]. Stewart, supra note 2 at para 584.

Ibid at para 647.

Ibid.

Chopra v T Eaton Co, [1999] 9 WWR 711 at para 85 (Alta QB), Brooker J.

Nigel Bankes, "Termination of an Oil and Gas Lease, Covenants as to Title, and Assessment of Damages for Wrongful Severance of Natural Resources: A Comment on Williston Wildcatters” (2005) 68:1 Sask L Rev 23 at 52-55.

See e.g. Canadian Export Gas \& Oil Ltd v Flegal (1977), 9 AR 105 (SC (TD)), Stevenson J (respecting the non-application of a traditional lease-based exception to the common law perpetuities rule to oil and gas leases). 
since an oil and gas lessee (occupying in ignorance) is in no different moral position than a traditional lessee (occupying in ignorance). These finer points did not figure in the decision of Chief Justice Gerein at trial in the Montreal Trust case. ${ }^{207}$ Chief Justice Gerein accepted that an overholding lessee committed trespass upon lease termination. ${ }^{208}$ The precedential value of this finding is weakened by the point having apparently been conceded without argument before the Saskatchewan Court of Appeal. ${ }^{209}$

The better view would appear to be that an overholding tenant, whether an oil and gas lessee or a traditional lessee, is not a trespasser but a tenant at sufferance: "A tenancy at sufferance arises where a tenant, having entered the land under a valid tenancy, holds over without the landlord's assent or dissent. Such a tenant differs from a trespasser in that his original entry was lawful, and from a tenant at will in that his tenancy exists without the landlord's consent." 210 That is, with Bankes, there is no trespass, but the landlord still has a cause of action: "the tenant at sufferance is liable to a claim for 'use and occupation' ... rather than to an action for damages for trespass or for mesne profits." ${ }^{211}$ The measure for use and occupation is "a reasonable sum, assessed at the ordinary market value, for the use and occupation of the land." 212 As will be seen below, this measure nicely matches the measure of damages settled upon by Justice Romaine.

If trespass were made out, the Defendants could advance the defence of "leave and licence" for the period in which they were granted consent to remain on the Lands. Justice Romaine indicated that she would have followed the Montreal Trust approach, such that leave and licence could have been granted by the freeholder Plaintiffs after they "came to the belief that the leases had terminated." ${ }^{213}$ Granting consent to a trespasser to remain on lands presupposes that a (former) lessor realized that the lease had terminated. While Justice Romaine did not elaborate, she suggests that she prefers the view expressed in Montreal Trust that the knowledge required to provide consent is the lessor's knowledge. Granting leave and licence need not await a final judicial determination which would authoritatively permit a lessor to know its rights. ${ }^{214}$ Justice Romaine, then, appears to be parting company with Justice Kent's approach to the knowledge element of leave and licence leave described

Montreal Trust Co v Williston Wildcatters Corp, 2003 SKQB 360, [2004] 3 WWR 574, Gerein CJ [Montreal Trust QB], rev'd 2004 SKCA 116, 243 DLR (4th) 317 [Montreal Trust CA], leave to appeal to SCC refused, 30596 (21 April 2005).

Montreal Trust QB, ibid, at para 6. Chief Justice Gerein also discussed case law pertaining to leave and license issues as opposed to whether an overholding lessee commits trespass: see Wurstemberger $v$ Royalite Oil Co, [1935] 2 DLR 177 (Alta SC (AD)) (cited in Montreal Trust QB, ibid at para 12); CPR $v$ The King, [1931] 2 DLR 386 (cited in Montreal Trust QB, ibid at para 8).

Montreal Trust CA, supra note 207 at para 18.

Charles Harpum, Stuart Bridge \& Martin Dixon, eds, Megarry \& Wade: The Law of Real Property, 8th ed (London: Sweet \& Maxwell, 2012) at 793 [footnotes omitted]. See also Dean and Chapter of the Cathedral and Metropolitan Church of Christ Canterbury v Whitbread (1995), 72 P \& CR 9 at 13 (Ch), Cooke J.

Harpum, Bridge \& Dixon, ibid at 793-94 [footnotes omitted]. See the discussion of "mesne profits" at 100: "the owner may elect to seek either restitution of the benefit which the defendant has received or damages for the loss he has suffered ... [u]sually ... compensation for having been deprived of use and occupation of the land" [footnotes omitted].

Ibid at 900-901 [footnotes omitted]. See also David R Percy \& David McGillivray, “Overlapping Remedies and the Unexpected Termination of Oil and Gas Leases” (2011) 49:2 Alta L Rev 251 at 263. Stewart, supra note 2 at para 667.

Montreal Trust CA, supra note 207 at paras 54, 56. 
in the Freyberg damages decision. ${ }^{215}$ Regardless, the leave and licence period would have been modest at best, amounting to about two years respecting one group of Plaintiffs. ${ }^{216}$

\title{
2. CONVERSION
}

Conversion is the "wrongful interference with the goods of another, such as taking, using, or destroying these goods in a manner inconsistent with the owner's right of possession."217 According to Osborne:

\begin{abstract}
There are three central elements to the tort of conversion. First, it protects persons who are in possession of chattels or who have a right to the immediate possession of chattels. Second, it is restricted to the intentional interference and dealing with chattels... Third, an act of conversion is one that so seriously interferes with the plaintiff's rights to the chattel that the defendant may, in fairness, be required to pay its full value. The payment of damages equivalent to the full value of the chattel is said to effect a forced judicial sale of the chattel to the defendant. This explains why orders for the return of the chattel are not made in a conversion action. The defendant is treated as if he had bought the chattel and he can keep it. ${ }^{218}$
\end{abstract}

The present case might seem an obvious example of conversion. The Defendants produced and sold the Plaintiffs' natural gas. Conversion was the basis for recovery in the Alberta Court of Queen's Bench decision on damages in the Freyberg case. ${ }^{219}$ There was a suggestion in Justice Romaine's reasons that the Court of Appeal had cast doubt on the availability of conversion to mines and minerals owners in Xerex, where the following passage is found:

The tort of conversion deals with interference to goods and chattels, rather than land. It follows from this that to be able to sue in conversion a plaintiff must be in possession of those goods or chattels, or have a right of immediate possession. There is a real question, therefore, whether the holder of a minerals rights licence, who has not yet exploited his interest, has an immediate right to the possession of substances that have not yet been severed from the ground. This is an unsettled area of the law, and because the trial judge did not award damages for conversion we see no reason to consider this issue further. ${ }^{220}$

Xerex dealt with a licencee or the holder of a profit à prendre, not a mines and minerals owner. If the licencee does not have the right to immediate possession of oil and gas, then the mines and minerals owner must (who else would?), thereby supporting the availability of the action for the owner. The allocation of the "right to immediate possession" as between a lessee and a lessor may be murky, but if (as in this case) the lease has terminated, the lessee could not assert a right to immediate possession, as against the lessor. Hence, again, the lessor, the Plaintiffs in this case, should have rights supporting an action in conversion.

Freyberg v Fletcher Challenge Oil \& Gas Inc, 2007 ABQB 353, [2007] 10 WWR 133, Kent J [Freyberg Damages] ("[a]lthough the validity of the lease was raised, only when the Supreme Court denied leave did the parties know that the lease was invalid" at para 135).

$216 \quad$ Stewart, supra note 2 at para 668. also Freyberg Damages, supra note 215 at para 147.

218 Osborne, supra note 196 at 308-309 [footnotes omitted]; Klar, supra note 88 at 99, 107.

${ }_{219}$ Freyberg Damages, supra note 215 at paras 101, 148; Stewart, supra note 2 at para 606.

$220 \quad$ Xerex, supra note 200 at para 89. 
Unfortunately, yet again for the Plaintiffs, their situation has complexities arising from the participation of the Jerome Group Plaintiffs. The natural gas was produced from the southeast quarter section. But insofar as that Lease could not be declared to have terminated, production under that Lease could not be wrongful. If the Plaintiffs and the Jerome Group Plaintiffs held undivided interests in the natural gas rights underlying the Lands (for example, as tenants in common), the Plaintiffs would not be excluded from a remedy. They could claim an accounting for the production of their share of the natural gas. The tenants in common theory, though, has no application in the circumstances. Whether or not the Scurry Leases subsisted, the liability and damages phase of this case proceeded on the basis that the other Leases had terminated. This would spell the end of the pooling arrangement, which was purely contractual. There was no evidence that each of the Plaintiffs (including the Jerome Group Plaintiffs) held undivided interests in the natural gas underlying the whole section through some other arrangement. The natural gas was produced only from Jerome Group Plaintiff Lands. Arguably, the Plaintiffs could have no claim to gas produced from the Jerome Group Plaintiff Lands, since the Plaintiffs' interests were lost through the rule of capture. $^{221}$ The gas that was produced was not theirs. This would not mean that the Defendants were not liable at all; it would mean that the Defendants were not liable to the Plaintiffs for conversion, but only to the Jerome Group Plaintiffs (if they were found to be entitled to a declaration of lease termination). Whether and on what terms the Jerome Group Plaintiffs would be obliged to account to the Plaintiffs is another matter.

Finally, what may completely undercut the Plaintiffs' conversion argument is that it appears that none of the natural gas produced was theirs or the Jerome Group Plaintiffs'. In separate proceedings the Defendants were pursued for converting the storage unit natural gas. The revived and recompleted 7-25 Well was, it appears, producing its neighbour's storage unit gas. This litigation led to the injunction that shut-in the 7-25 Well. In that litigation, the Defendants third-partied the Plaintiffs, seeking repayment of royalties (which, if the storage unit arguments prevail, the Plaintiffs never should have received). ${ }^{222}$ The Plaintiffs should have no cause of action for the production of natural gas that was not theirs. ${ }^{223}$

\section{MeAsure OF DAMAgES IN TORT}

Hanging over the law of damages for the post-lease termination conduct of lessees, like a declaration of the Oracle of Delphi, is the decision of the Saskatchewan Court of Appeal and the Supreme Court in Sohio:

The appellant also sought an accounting of all petroleum, natural gas and related hydrocarbons removed from the land by the respondents, or damages in lieu thereof. The Court has jurisdiction to grant this relief on terms which will be just and equitable to all parties involved. The respondent Sohio proceeded under a mistake as to its rights, and did not knowingly take an unfair advantage of the appellant's lack of appreciation of its legal rights. The respondents were first aware that their position was challenged when the writ of summons was served upon them. At that time the revenue which they had received from the sale of the

Borys, supra note 124.

Stewart, supra note 2 at para 657.

It appears that the gas storage unit parties have entered into a settlement agreement with the Plaintiffs; in an exchange for undisclosed compensation, the freehold Plaintiffs granted storage leases to the gas storage unit parties: ibid at para 658 . 
production exceeded the amount they had expended. Under the circumstances, it would appear just and equitable to order the respondents to account for all benefits from production received by them after the date of service of the writ of summons upon them. ${ }^{224}$

As is typical of oracular pronouncements, this declaration is enigmatic, providing little concrete guidance for practical life. We are directed, though, to seek remedies that are "just and equitable to all parties involved.” If the Plaintiffs established trespass or conversion or both, how would their damages be measured?

The common law provides some guidance for achieving just and equitable results. The basic approach to torts damages is compensatory. The plaintiff should be put in the position that the plaintiff would have been in had the tort not occurred: "Damages are measured by the plaintiff's loss, not the defendant's gain." 225 This basic approach is supplemented if additional factors are engaged. The conduct of the defendant may warrant denunciation, a civil law response to the gravity of the harm and the blameworthiness of the tortfeasor. The conduct of the defendant may warrant deterrent measures, to dissuade others from engaging in similar conduct. The defendant may have profited by its wrong. To avoid promoting wrongdoing and to avoid allowing wrongdoers to profit by their wrongs, benefits obtained by the defendant may be stripped away. ${ }^{226}$ Profit may be stripped through an award of punitive damages. ${ }^{227}$ Further, a plaintiff may attach benefits secured by a tortfeasor through "waiver of tort." ${ }^{228}$ In this instance, the plaintiff would claim disgorgement of the defendant's profits. Damages are measured not by what the plaintiff has lost but by what the defendant has gained. ${ }^{229}$ Since the goal is to strip a defendant of wrongful profits, there is no need for a correspondence or correlation between the profits sought and a deprivation of the plaintiff. ${ }^{230}$ The remedy, then, is not (properly speaking) "restitutionary" since it does not aim at returning a lost benefit to a plaintiff. The justification for the remedy is the breach of a positive obligation by the defendant, coupled with profit from that wrongdoing. ${ }^{231}$

A tortfeasor's level of moral turpitude may vary, as may its contribution to any profits founded on its wrongdoing. The courts have therefore developed several categories of cases to aid in the determination of appropriate profit-stripping awards in lease termination cases. If the defendant's conduct was highly reprehensible (involving, for example, bad faith, dishonesty, fraud, or the willful violation of the plaintiff's rights), the plaintiff may be

Weyburn Security Co Ltd v Sohio Petroleum Co (1969), 7 DLR (3d) 277 at 283 (Sask CA), Hall JA, cited in Sohio, supra note 55 at 89.

Stewart, supra note 2 at para 637; AG v Blake, [2000] 4 All ER 385 at 391 (HL), Lord Nicholls; Montreal Trust CA, supra note 207 at 72, 110.

Stewart, ibid ("[i]f the circumstances of the situation require more punitive measures, because the behaviour 'offends the conscience of the court' or because relief needs to act as a deterrent to such wrongdoing on future occasions, those measures may include disgorgement of profit” at para 636).

Peter D Maddaugh \& John D McCamus, The Law of Restitution (Toronto: Thomson Reuters, 2014) (loose-leaf December 2014 supplement) vol 2, ch 24 at 33; Jamie Cassels \& Elizabeth Adjin-Tettey, Remedies: The Law of Damages, 3rd ed (Toronto: Irwin Law, 2014) at 320-22, 334.

Cassels \& Adjin-Tettey, ibid at 294.

Montreal Trust CA, supra note 207 at paras 75-76.

Mitchell McInnes, "Resisting Temptations to 'Justice”" in Robert Chambers, Charles Mitchell \& James Penner, eds, Philosophical Foundations of the Law of Unjust Enrichment (New York: Oxford University Press, 2009) 100 at 106 [McInnes, "Resisting Temptations"] (the benefit disgorged may in fact have been received by the defendant from a third party, without the plaintiff ever having had the possibility of obtaining this benefit on its own).

Ibid. 
awarded the full value of product extracted the lands, with no deductions. If the defendant's conduct was reprehensible but not innocent, so that there would be no concern about overcompensating the plaintiff, the plaintiff may be awarded the value of the product extracted, less post-severance deductions (transportation costs). ${ }^{232}$ If the defendant's conduct was not reprehensible (that is, if the defendant was an innocent tortfeasor) such that there would be concerns about over-compensating the plaintiff, the approach to damages (re)turns from the defendant's culpability to the plaintiff's injury and a mild approach is used. ${ }^{233}$

Two types of cases have emerged under the "mild" heading. If the plaintiff could have developed the lands itself (that is, the defendant took from the plaintiff the opportunity to do what it had done), the plaintiff may be awarded damages based on the value of the product extracted, less post-severance costs (transportation) and processing costs, and severance costs. ${ }^{234}$ If the plaintiff could not have developed the lands itself, the defendant's conduct blocked the plaintiff from re-leasing the lands, which (having been proven to be productive) would have resulted in an upfront bonus plus an enhanced royalty (less any royalties that were paid). ${ }^{235}$ As Justice Poelman has observed, “[t]he authorities make it difficult to draw much distinction between the 'mild' form of restitutionary damages and the compensatory measure of damages." ${ }^{236}$ The mild remedies are in the spirit of relief that is just and equitable to both plaintiff and defendant.

The "bonus plus best royalties" approach has been criticized. First, John Ballem has asserted that the inquiry into whether a lessor could or could not develop the lands by himself is inappropriate. The courts are "ill-equipped" to "delve into the affairs of the plaintiff."237 Courts, though, frequently delve. Criminal sentencing, the determination of damages in personal injury cases, and custody hearings - among many other types of litigation involve examinations of individuals' affairs. Furthermore, evidence can be tendered respecting the expertise and experience necessary to engage in oil and gas contracting and respecting opportunities and obstacles for small prospective operators. ${ }^{238}$ Second, in Livingstone, ${ }^{239}$ which is foundational to the "bonus and best royalties" approach to damages, "Lord Blackburn was careful to note ... that he did not think that the decision of the Court of Session (which was upheld by the House of Lords) is that 'the royalty is the measure of the damages. It is only that it is evidence of the value which is the measures of the damages.” 240 Livingstone was not creating a new rule, but was a decision based on the best evidence of a particular plaintiff's loss. The argument is that it was an exceptional decision dealing with exceptional circumstances. ${ }^{241}$ The exceptional nature of the decision could be conceded in its home environment. In the Prairie West, however, with its atomized freehold resource ownership, small isolated owners with no industry experience, significant economic

$232 \quad$ Montreal Trust CA, supra note 207 at para 79.

$233 \quad$ Ibid at para 80; Freyberg Damages, supra note 215 at para 131.

$234 \quad$ Montreal Trust QB, supra note 207 at para 80.

235 Ibid at para 110; Stewart, supra note 2 at paras 636, 643.

$236 \quad$ Nexxtep Resources Ltd v Talisman Energy Inc, 2012 ABQB 62, [2012] 10 WWR 528 at para 72, aff'd supra note 122.

John Bishop Ballem, “The Further Adventures and Strange Afterlife of the Oil and Gas Lease” (2006) 44:2 Alta L Rev 429 at 438.

For a summary of the difficulties that an individual freeholder would have in seeking to develop lands as a working interest owner, see Simard, Holub \& Taylor, supra note 150 at 324-26.

Livingstone v Rawyards Coal Co (1880), 5 AC 25 (HL (Scot)).

Montreal Trust CA, supra note 207 at para 72 [footnotes omitted].

See Bankes, supra note 205 at 71. 
influence, or personal capital reserves sitting on personally unexploitable riches, what may have been exceptional elsewhere is normal here. Third, the "bonus plus best royalty" approach does create the risk of inclining lessees to remain on lands, even though they suspect or even know that leases have terminated. The worst that could happen is that they wind up paying just marginally more than they would have under the original lease. ${ }^{242}$ This risk was recognized in Montreal Trust CA:

\begin{abstract}
Although such refinement does give the trespasser the profit it would have received had they acted lawfully, such result is justified by reason of the lack of bad faith or the mistaken belief that they were acting lawfully, and it is preferable to giving the plaintiff a windfall profit in such circumstances. Arguments that suggest that this will encourage trespassers to be careless as to whether they act legally or not should be instantly quelled: a trespasser who does so is almost certain to fall under the harsher head of damage due to their negligence or bad faith, and thus this option of damages is not even open to the court. ${ }^{243}$
\end{abstract}

In this case, the Defendants profited from production from the recompleted 7-25 Well. The Plaintiffs contended that they were entitled to profits, and claimed disgorgement of gross proceeds of sale or disgorgement of net operating income. ${ }^{244}$ The Defendants responded that the Plaintiffs would be adequately compensated if they received the royalty and bonus that they would have received, had new leases been negotiated when the Leases terminated. ${ }^{245}$ The Defendants, then, would retain profits net of bonus and incremental royalty payments.

Justice Romaine adopted the Montreal Trust and Freyberg Damages approach to assessing damages. She found no evidence taking the Defendants out of the "innocent tortfeasor" category. They engaged in no conduct that would warrant a punitive or deterrence-based damage award. Neither, then, were either of the two "harsh" profit-stripping approaches appropriate. None of the parties was aware that that the Leases had terminated in the mid-1990s. ${ }^{246}$ The fact that the Defendants remained in possession after service of the Statement of Claim did not warrant a harsher measure of damages. Whether the Leases remained valid was not "clear-cut." Furthermore, Snell Farms and Wheatland were not parties, so the Defendants had to consider any obligations owed to them. ${ }^{247}$

The Plaintiffs sought to evade the finding that they could not have operated the 7-25 Well on their own. The freehold Plaintiffs had entered into top leases, so FSI or 108 could have operated the well. Justice Romaine drew a contrary conclusion. What these arrangements established was that the freehold Plaintiffs were unable to develop the Lands on their own. They needed industry assistance. The best they could do was what they did, which was to enter into a new lease; the Plaintiffs themselves could never develop the Lands. ${ }^{248}$

Ballem, supra note 237; Percy \& McGillivray, supra note 212 at 270; Bankes, supra note 205 at 57. Montreal Trust CA, supra note 207 at para 110.

Stewart, supra note 2 at para 581.

Ibid at para 582.

Ibid at paras 646, 649, 663.

Ibid at para 649.

Ibid at para 656. Furthermore, neither could the Top Lessees develop the Lands. It appears that the TopLessee Plaintiffs assigned their interests under the top leases to the gas storage unit parties, save for "their right to prosecute and their right to retain the proceeds of this litigation" (at para 658). 


\section{B. UNJUST ENRICHMENT}

Should traditional common law causes of action have been found to be unavailable to the Plaintiffs, one might have hoped and expected that some other legal framework could address the Defendants' unauthorized occupation and production. Unjust enrichment would appear to fill any gaps left by the law of torts. Establishing this cause of action might be thought to be useful to the Plaintiffs, since the remedy for unjust enrichment is a requirement to "repay or reverse the unjustified enrichment."249 "[T] he courts have no business in substituting a tort remedy on the grounds that it seems fairer."250 Justice Romaine pointed to the availability of a cause of action in unjust enrichment, without detailing its application. ${ }^{251}$

It is important to begin with the acknowledgement that unjust enrichment is distinct if not always separate from actions in contract and torts. It embraces a third type of cause of action. $^{252}$ It does not turn on the fault of breaking promises or injuring others or their property. Instead, the cause of action reverses transactions that may be completely "blameless" from other legal perspectives: "the action in unjust enrichment involves true strict liability. Liability is imposed, despite the absence of any breach, simply because the defendant received an unwarranted benefit from the plaintiff."253

The main elements of a cause of action in unjust enrichment are well established: “(1) enrichment of the defendant; (2) a corresponding deprivation of the plaintiff; and (3) an absence of juristic reason for the enrichment." ${ }^{\text {"254 }}$ Benefit and deprivation are economic in nature. While a benefit must be tangible, "[i]t may be positive or negative, the latter in the sense that the benefit conferred on the defendant spares him or her an expense he or she would have had to undertake.”255 There must be a material connection or linkage between the enrichment and the measureable loss or diminution of the plaintiff's resources. ${ }^{256}$ Further, there must be a "matching plus and minus;"257 "the second requirement obligates the plaintiff to establish not simply that the defendant has been enriched, but also that the enrichment corresponds to a deprivation which the plaintiff has suffered."258

The Supreme Court established a two-step approach to the "absence of juristic reason” element in Garland:

First, the plaintiff must show that no juristic reason from an established category exists to deny recovery....

The established categories that can constitute juristic reasons include a contract, a disposition of law, a

Kerr v Baranow, 2011 SCC 10, [2011] 1 SCR 269 at para 46, Cromwell JA [Kerr]. See also Mitchell McInnes, "A Return to First Principles in Unjust Enrichment: Kerr v Baranow” (2001) 51:2 Can Bus LJ 275 [McInnes, "First Principles"].

Percy \& McGillivray, supra note 212 at 271.

Stewart, supra note 2 at paras 586-87.

McInnes, "Resisting Temptation,” supra note 230 at 103.

McInnes, "First Principles," supra note 249 at 275, n 5 [citations omitted]. See also ibid at 103.

Garland v Consumers’ Gas Co, 2004 SCC 25, [2004] 1 SCR 629 at para 30, Iacobucci JA [Garland] [citations omitted]. See also Kerr, supra note 249 at paras 36, 38, 39. The transfer of value from plaintiff to defendant is reversed if the transfer lacked any legal basis or fulfilled no legal purpose (McInnes, "First Principles," ibid at 279, 281).

Kerr, ibid at para 38.

Critically, there must be a material connection or linkage between the enrichment and a measurable loss or diminution of a plaintiff's resources: McInnes, "Resisting Temptation,” supra note 230 at 104.

McInnes, "First Principles," supra note 249 at 283.

Kerr, supra note 249 at para 39 [citations omitted]. 
donative intent, and other valid common law, equitable or statutory obligations. If there is no juristic reason from an established category, then the plaintiff has made out a prima facie case under the juristic reason component of the analysis.

The prima facie case is rebuttable, however, where the defendant can show that there is another reason to deny recovery. As a result, there is a de facto burden of proof placed on the defendant to show the reason why the enrichment should be retained. This stage of the analysis thus provides for a category of residual defence in which courts can look to all of the circumstances of the transaction in order to determine whether there is another reason to deny recovery.

As part of the defendant's attempt to rebut, courts should have regard to two factors: the reasonable expectations of the parties, and public policy considerations. ${ }^{259}$

Even if the elements of unjust enrichment are made out, a defence may be available to the defendant, such as the defence of change of position "where an innocent defendant demonstrates that it has materially changed its position as a result of an enrichment such that it would be inequitable to require the benefit to be returned." ${ }^{260}$ The defence is available, in the words of Lord Goff, if "the injustice of requiring [the innocent defendant] so to repay outweighs the injustice of denying the plaintiff restitution." 261 Depending on the nature of the enrichment and whether it can be traced into some asset or assets, the appropriate form of remedy could be a monetary payment or a proprietary remedy. ${ }^{262}$

In this case, the Defendants did not make money from 1995 to 2001, since the 7-25 Well was shut-in. The Defendants certainly made money from 2001 to 2011. Their economic benefit was achieved by producing (assuming for now) the Plaintiffs' natural gas. No gas, no profit. But what was the Defendants' enrichment, what was the Plaintiffs' corresponding deprivation, and was there any juristic reason for permitting the Defendants to retain any enrichment?

Setting aside the drilling and completion and re-completion costs of the 7-25 Well (that is, on the assumption that those expenses had been recouped before the well was shut-in) the value of enrichment cannot be the full sales price of the natural gas. The Defendants were not enriched by that amount. They were enriched by the difference between the price of the natural gas and their expenses: operating costs, processing costs, transportation costs, and royalty costs. These amounts, at least, must be deducted to work out the value of the gas lost by the Plaintiffs to the Defendants.

As seen above, the evidence did not support the conclusion that the Plaintiffs could have developed the Lands themselves. They were not natural gas producers. They were not deprived of the flow of gas, net of expenses. At best, they would have relied on some other party to do the work for them. Add to the deductions from the sales price, then, a profit margin recoverable by that other party connected with its operation of the 7-25 Well.

Garland, supra note 254 at paras 44-46 [citations omitted]. Maddaugh \& McCamus, supra note 227, vol 1 , ch 3 at 35, 39.

260 Garland, ibid at para 63 [citations omitted]. See also Maddaugh \& McCamus, ibid, vol 1, ch 3 at 49-50.

261 Lipkin Gorman v Karpnale Ltd, [1992] 4 All ER 512 at 533 (HL), Lord Goff.

$262 \quad$ Kerr, supra note 249 at para 47. 
Furthermore, keeping in mind that the burden of proof lies on the Plaintiffs, the evidence did not show that this other party would do the work on a service-contract basis only. An equally reasonable inference is that the only way to induce a new party to develop the Lands would have been through granting it a new lease. What the Plaintiffs were deprived of was the best available royalty. This corresponded to a "negative" enrichment of the Defendants, the bonus and marginal increase of royalty the Defendants did not pay. We arrive again, through unjust enrichment, at the "bonus and best royalty" measure of damages.

If there were an enrichment and a corresponding deprivation, were the Defendants immunized from liability to the Plaintiffs in whole or in part through the operation of a juristic reason justifying retention of the enrichment? No established category of juristic reason was engaged. Was there is another reason to deny recovery? Prior to the Plaintiffs having come to the conclusion that the Leases had terminated and their notification of termination to the Defendants, the Plaintiffs and Defendants were operating under a mutual legal mistake. The Defendants were producing the Plaintiffs' natural gas; but the Defendants were operating the Well, incurring the required expenses, and paying royalties. Both sets of parties believed that Leases that had been valid remained valid. Expectations remained fulfilled. The Defendants' position might be analogized to that of Consumer's Gas in Garland. Consumer's Gas relied on Ontario Energy Board orders to collect excessive amounts from consumers. Initially, it was not appreciated that the orders were illegal. During this period, Consumer's Gas reasonably relied on the orders. This supported a juristic reason for denying recovery of the over-charges during this period:

For the period between 1981 and 1994, when the current action was commenced, there is no suggestion that Consumers' Gas was aware that the LPPs violated s. 347 of the Criminal Code. This mitigates in favour of Consumers' Gas during this period. The reliance of Consumers' Gas on the OEB orders, in the absence of actual or constructive notice that the orders were inoperative, is sufficient to provide a juristic reason for Consumers' Gas's enrichment during this first period. ${ }^{263}$

When, however, the action was commenced against Consumer's Gas respecting the overcharges, the serious possibility of the illegality of the orders was raised and Consumer's Gas was no longer entitled to reasonably rely on those orders. From that point forward its enrichment was not supported by a juristic reason. "After the action was commenced and Consumers' Gas was put on notice that there was a serious possibility the LPPs violated the Criminal Code, it was no longer reasonable for Consumers' Gas to rely on the OEB rate orders to authorize the LPPs."264 Similarly, once the Defendants had been notified by the Plaintiffs that the Leases had terminated, a "serious possibility" of the Leases' invalidity was raised, and the Defendants were no longer entitled to reasonably rely on those Leases. Arguably, intuitions of what is just and unjust intersect with the common law of trespass. The overholding tenant commits trespass only when its licence is revoked; the Defendants' enrichment became unjust only following notice of termination of the Leases.

But again, the provenance of the natural gas cannot be forgotten. If the natural gas produced between 2001 and 2011 did not belong to the Plaintiffs, it could not be just to 
compensate the Plaintiffs for what they did not lose. It would not be unjust for the Plaintiffs not to acquire a share of what should not have been produced.

\section{CONCLUSION}

Stewart is a lengthy journey through many issues in freehold lease litigation. This type of litigation is a steep climb for lessors. Issues of property law must be sorted out to ensure that the right parties come forward. Limitation periods are short, especially since most lessors will begin from a serious information deficit respecting industry operations on their property. Leases are to be interpreted to benefit both parties, but one might be excused for translating that comment as "sometimes you eat the bear, sometimes the bear eats you.” If a court does find that a lease has terminated, a lessor may be surprised to find that the economic reality after the termination looks a lot like the economic reality before the termination: there was a lease, then it was as if there were a lease. But pessimism is not (always) justified: at least if lands remain valuable, the new lease could come with a big bonus and bumped-up royalty. And since they are not making any new land but they are making new production technologies, there's a reasonable prospect that freeholders in the position of the Stewart plaintiffs could come into new money from old wells. 